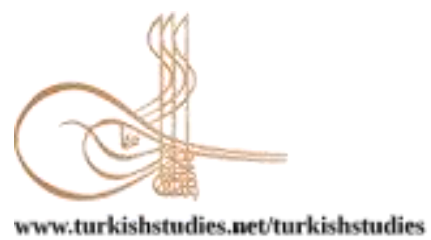

Turkish Studies

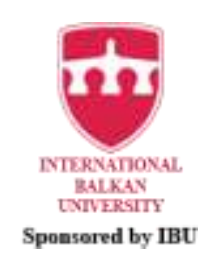

\title{
Paydaşlar Kapitalizminde Katılım Bankacılığının Önemi
}

\author{
The Importance of Participation Banking in Stakeholders Capitalism
}

\author{
Resül Yazıcı*
}

\begin{abstract}
The main views of economics according to the basis of ownership are between investor capitalism and state capitalism. In the view of investor capitalism, whose best known expression is liberalism, it is assumed that owners of capital will contribute to the welfare of society while maximizing their profits. In state capitalism, on the other hand, it is basically advocated that the order that will provide the welfare of the society fairly will be established with the capital's belonging to the state or its intervention. However, companies managed with excessive profit ambitions cause various problems. The first form of these problems is experienced through natural disasters because of a destroyed and naturally damaged environment and the phenomenon of global warming. The second important negativity is the day by day increasing number of desperate people, due to the turmoil and civil wars caused by excessive income distribution injustices. Therefore, today where both extreme approaches fail, it is expected to do more from companies and shareholders, which are the main reason for this. The main purpose of this expectation is to ensure that sustainable development and activities can be carried out on our planet. For this, the concept of stakeholder capitalism, which covers all parties, has come up. In this study, by referring to the roles of the parties / stakeholders, it will be tried to give how the of the stakeholder capitalism can be realized with the new regulations to be made. Particularly in the financing activities of enterprises, examples of financing instruments that participation banking can develop will be given, and the importance of the financial system in achieving this goal will be explained.
\end{abstract}

Structured Abstract: The main views of economics according to the basis of ownership are between investor capitalism and state capitalism. In the view of investor capitalism, whose best known expression is liberalism, it is assumed that owners of capital will contribute to the welfare of society while maximizing their profits. In state capitalism, on the other hand, it is basically advocated that the order that will provide the welfare of the society fairly will be established with the capital's belonging to the state or its intervention. However, companies managed with excessive profit ambitions cause various problems. The first form of these problems is experienced through natural disasters because of a destroyed and naturally damaged environment and the phenomenon of global warming. The second important negativity is the day by day increasing number of desperate people, due to the turmoil and civil wars caused by excessive income distribution injustices. Therefore, today where both extreme approaches fail, it is expected to do more from companies and shareholders, which are the main reason for this. The main purpose of this expectation is to ensure that sustainable development and activities can be carried out on our planet. For this, the concept of

\footnotetext{
${ }^{*}$ Doç. Dr., Bilecik Şeyh Edebali Üniversitesi, İ̈BF, İktisat Bölümü

Assoc. Prof. Dr., Bilecik Şeyh Edebali University, Faculty of Economics and Administrative Sciences, Department of Economics,

ORCID 0000-0002-7875-3331
}

resul.yazici@bilecik.edu.tr

Cite as/ Atıf: Yazıcı, R. (2021). Paydaşlar kapitalizminde katılım bankacılığının önemi. Turkish Studies, 16(2), 805825. https://dx.doi.org/10.7827/TurkishStudies.47714

Received/Geliş: 19 November/Kasım 2020

Accepted/Kabul: 25 April/Nisan 2021

Checked by plagiarism software

Published/Yayın: 30 April/Nisan 2021

CC BY-NC 4.0 
stakeholder capitalism, which covers all parties, has come up. In this study, by referring to the roles of the parties / stakeholders, it will be tried to give how the of the stakeholder capitalism can be realized with the new regulations to be made. Particularly in the financing activities of enterprises, examples of financing instruments that participation banking can develop will be given, and the importance of the financial system in achieving this goal will be explained.

With the concept of stakeholder capitalism, the aim is to increase the level of economic development. So, in factors like social, cultural, environmental, etc. positive changes in the quality of life of both individuals and societies can be realized. The purpose of carrying out business activities, which are the subject of such restructuring, should not only be increasing profitability. Stakeholders should not be seen as the best instrument for increasing profits. Companies should share their revenues with their employees to the extent of their contributions, with other companies in the supply chain, with their customers; briefly, they should share with all factors directly or indirectly involved in production and the aftermath process. Since this sharing would not be voluntary, both locally and globally regulatory and supervisory institutions have great duties. These institutions, in the private or public sector, from service supply to product development; from the regulation to supervision of business activities or public services; should be equipped with capacities to regulate the system with an idea, behavior and way of doing business, which can be applied in all areas of daily life.

While human beings were trying to find and rule these systems by trial / error (in other words, for the purpose of ensuring justice in the distribution of income and wealth of stakeholder capitalism), Islam found a solution with its unique tools (haram of interest, zakat, fitrah, etc.) on how to achieve this. Therefore, the economic structure that will ensure the achievement of the objectives of stakeholders' capitalism and the financial system affecting it, should be participation banking. For, unlike traditional banking, which has been tested and has only served to the capitalists and shareholders, participation banking operates on the interestfree principle.

An important reason why participation banking in Turkey has not improved is that Turkey is experiencing the "inflation, interest rate, devaluation" spiral. Therefore, both decrease in the inflation rate and reduction of the inflation uncertainty in Turkey, means the elimination of the obstacles for the development of this system to a large extent. Otherwise, the decrease in the internal and external value of the local currency for various reasons negatively affects its feature of value storing. In this case, Muslim individuals tend to save under the mattress or to substitute money, both because of not wanting to be involved in interest, and because of their distrust in the financial system. In order to alleviate these negativities in the short term, tools to direct the savings of these segments to investment instruments indexed to inflation rates or linked to products such as foreign currency or gold, should be developed by participation banks. Thus, thanks to new interest-free products that can be offered to both the investor requesting funds and the saver, the weight of participation banks in the economy will increase. Another important problem of the traditional financial systems is that there is an unfair distribution in the use of their resources. It should be ensured that these resources are distributed fairly between SMEs that will prepare the most common employment conditions, and people and institutions which will produce the required amount of goods and services that the society needs, instead of the wealthy and powerful ones. For this, participation banking should be supported with the necessary incentives that can be given by the public. Otherwise, the unfair situation in access to finance will continue.

By developing financial instruments for both individuals and corporate customers, participation banking has the potential to operate in capital markets with capital market instruments that comply with its working principles. The approach here should be based on the logic of labor / capital partnership, both to launch interest-free products and to increase the level of financial literacy. Thus, pre-existing insecurity can also be removed. With their combined power and synergy, the growth of participation banking and capital markets will be realized more easily. In addition to achieving this transformation in the financial system, it is of great importance to establish and operate independent regulatory and supervisory structures both locally and globally. After their establishment, running these structures depends on the success in institutionalization in structures at all levels. Briefly, if the transformation and unity in the financial system, and in the unfair traditional structure of access to finance, cannot be achieved; also a failure of independent regulatory and supervisory structures to work effectively will make it difficult for stakeholder capitalism to achieve its aim. 
Keywords: Finance System, traditional banking, participation banking, stakeholders capitalism, sustainable development, regulatory and supervisory institutions

Öz: Ana akım iktisadın mülkiyet esasına göre temel görüşleri, sermayedarlar kapitalizmi ile devlet kapitalizmi arasındadır. En bilinen ifadesi liberalizm olan sermayedarlar kapitalizmi görüşünde, sermaye sahiplerinin, kendi karlarını maksimize ederken toplum refahına katkıda bulunacağı varsayılır. Devlet kapitalizminde ise temel olarak sermayenin devlete ait olmasiyla veya onun müdahale etmesiyle, toplum refahını adil bir şekilde sağlayacak düzenin kurulacağı görüşü savunulur. Fakat şirketlerin, aşırı kar hırsıyla yönettikleri işletmeler, başta iklim krizi olmak üzere çeşitli olumsuzluklara neden olmaktadır. Bunların herkes tarafindan görünen birinci şekli, tahrip edilmiş ve doğal yapısı bozulmuş bir çevre ve küresel ısınma olgusuyla yaşanan doğal felaketlerdir. İkinci önemli olumsuzluk da, aşırı gelir dağılımı adaletsizliklerinin neden olduğu kargaşalar ve iç savaşlar sonucunda gezegenimizde sayısı her geçen gün artan umutsuz insanlardır. Dolayısıyla her iki uç yaklaşımın iflas ettiği günümüzde, bunun temel sebebi olan şirketlerden ve hissedarlarından daha fazlasını yapması beklenmektedir. $\mathrm{Bu}$ beklentinin temel amacı gezegende sürdürülebilir kalkınmanın, faaliyetlerin yürütülebilmesinin sağlanabilmesidir. Bunun için de tüm tarafları kapsayan paydaşlar kapitalizmi kavramı gündeme gelmiştir. $\mathrm{Bu}$ yaklaşım, işletmelerin faaliyetlerini yürütürken taraf olduğu tüm paydaşların hakkını gözetmelerine işaret etmektedir. Çalışmada, tarafların/paydaşların rollerine değinilerek, yapılması gereken yeni düzenlemelerle, paydaşlar kapitalizminin nasıl gerçekleştirilebileceği verilmeye çalışılacaktır. Özellikle işletmelerin finansman faaliyetlerinde, katılım bankacılığının geliştirebileceği finansman araçlarıyla ilgili örnekler verilerek bu amaca ulaşmada finansal sistemin önemi, yapabilecekleri de aktarılmaya çalışılacaktır.

Anahtar Kelimeler: Finans Sistemi, geleneksel bankacılık, katılım bankacılı̆̆ı, paydaşlar kapitalizmi, sürdürülebilir kalkınma, düzenleyici ve denetleyici kurumlar

\section{Giriş}

Ana akım iktisadın mülkiyet esasına göre temel görüşleri, sermayedarlar/hissedarlar kapitalizmi ile devlet kapitalizmi arasındadır. En bilinen ifadesi liberalizm olan birinci görüşte, sermaye sahiplerinin, kendi karlarını maksimize ederken toplum refahına katkıda bulunulacağı vurgulanır. İkincisinde ise temel olarak sermayenin devlete ait olmasıyla veya onun müdahale etmesiyle, toplum refahını adil bir şekilde sağlayacak düzenin kurulacağı görüşü savunulur. Fakat bugünkü tabloda, kar hırsıyla görmezden gelinen, tahrip edilmiş ve doğal yapısı bozulmuş bir çevrede, gelir dağılımı adaletsizliklerinin sebep olduğu kargaşaları ve iç savaşlarla yaşanan göçler sonucunda umutsuz dünya insanları görülmektedir. Dolayısıyla her iki uç yaklaşımın iflas ettiği günümüzde, bunun temel sebebi olan firmalardan ve/veya sermayedarlardan daha fazlasını yapmas1 bekleniyor ki, amaç sürdürülebilir kalkınmanın sağlanabilmesidir. Bunun için de tüm tarafları kapsayan paydaşlar kapitalizmi kavramı gündeme gelmiştir.

Paydaşlar kapitalizmi kavramı öncesinde Friedman (1970) tarafından kullanılan hissedarlar kapitalizmi kavramında, iş dünyasının tek sosyal sorumluluğu, sahtekârlık ve aldatma olmadan, serbest ve açık bir rekabet ortamında kazançlarını arttırmak olarak ifade edilmişti. Bu şekildeki yaklaşım temel iki amaca ulaşmayı hedeflemekteydi: Birincisinde kar maksimizasyonuna ulaşırken toplumsal faydanın da sağlanacağı, ikincisinde ise hissedarlar için kar üretildiği sürece büyük yeni yatırımlar mümkün olacaktı.

$\mathrm{Bu}$ amaçlara ulaşmada özellikle birincisine özen gösterilmeden sadece ikinci amaca hizmet edildiği için ortaya çıkan sorunların nedeni olarak görülen hissedarlar kapitalizmi yerine önerilen çözüm, Dünya Ekonomik Forumu (World Economic Forum) kurucusu ve Chief Executive Officer (CEO'su) Schwab (2020) tarafından 1973'teki zirvede açıkladığı paydaşlar kapitalizmidir. O yıllardan bugüne paydaşlar kapitalizmi kavramının niçin önemli olduğu, yaşanılan sorunların sebeplerinde ve çözüm önerilerinde yatmaktadır. 
$\mathrm{Bu}$ kavramın veya gerçekleştirilmesi gereken dönüşümün amacı, ekonomik gelişmişlik seviyesinin artırılmasıyla birlikte, sosyal, kültürel, çevresel vb. gibi faktörlerde, hem bireylerin hem de toplumların yaşam kalitelerinde olumlu yöndeki değişimleri gerçekleştirmektir. Bu şekildeki değişimin, yapılanmanın öznesi olan işletme faaliyetlerinin yürütülmesinde amaç sadece kârlılı̆̆ın artırılması olmamalıdır. Tokalak'a (2016) göre de kapitalist sistemin anlayışı, bireyin yalnızca kendi çıkarını maksimize etmeye yönelik yaklaşımları, bireyde insani olmayan tutum ve davranışları ön plana çıkarmaktadır. Bu durum bireylerde egoizm ve para hırsını artırmaktadır. Birey kendi çıkarları pahasına insani değerleri hiç çekinmeden yerle bir edebilmektedir. Ayrıca üretimde odaklanılan en temel unsurun maliyet minimizasyonu olması, çevreyi koruma harcamaları yapılmadığı için onun büyük ölçüde tahrip edilmesi, sürdürülebilir kalkınma kavramının önemi her geçen gün artmaktadır.

Bu sorunların çözümünün temelinde paydaşların, karın maksimizasyonu için en iyi araçlar olarak görülmemesi yatmaktadır. Şirketler, gelirlerini, üretimde ve sonrasındaki süreçte direkt veya dolaylı yer alan tüm aktörlerle, (çalışanlarıyla, tedarik zincirinde yer alan diğer firmalarla, müşterileriyle) katkıları ölçüsünde paylaşmalıdır. Yani işletmeler, faaliyetlerindeki tüm paydaşların açık ve örtük maliyetlerini dikkate alarak, gerekli paylaşımları yaparak kâr/zarar hesabı yapmalıdırlar. Kısacası bu hesaplamada, sadece kendi karlarını maksimize etme yaklaşımında olmamalıdırlar. Bu amaçlara ulaşmak için de, hem yerel hem de küresel ölçekteki düzenleyici ve denetleyici yapılara büyük görevler düşmektedir.

$\mathrm{Bu}$ olumsuzlukların nasıl ortadan kaldırılabilileceği sorusu çalışmanın amacını oluşturmaktadır. Çalışmada tarafların/paydaşların rollerine değinilerek, yapılması gereken yeni düzenlemelerle, paydaşlar kapitalizminin nasıl gerçekleştirilebileceği verilmeye çalışılacaktır. Özellikle işletmelerin finansman faaliyetlerinde, katılım bankacılığının geliştirebileceği finansman araçlarıyla ilgili örnekler verilerek bu amaca ulaşmada finansal sistemin önemi, yapabilecekleri de aktarılmaya çalışılacaktır. Çalışmanın ilk alt başlığında, iş dünyasındaki temel paydaşların sistemdeki rolleri incelenecektir. Sonrasında, sistemdeki bu paydaşlar arasında adil dağılımın sağlanması için gerekli kuralların, düzenleyici ve denetleyici kurumlar tarafından düzenlenmesinin, işletilmesinin önemi verilecektir. $\mathrm{Bu}$ başlık birbirini tamamlayan, piyasaların düzenlenmesi ve denetiminde kurumsal yönetimin önemi; vekâlet çatışmalarının önlenebilmesinde kurumsal yönetimin önemi ve İslam iktisadının kurumsal yönetim ve vekâlet sorununa bakışı başlıklarıyla konunun önemi açıklanacaktır. Sonraki başlıkta paydaşlar kapitalizmine İslam'ın bakışı verilecektir. Paydaşlar kapitalizminde tüm tarafları etkileme gücüne sahip finansal sistemin önemi de son alt başlıkta işlenecektir. Bu başlıkta geleneksel bankacılıktaki finansal sistemin sorunlarına ve katılım bankacılığının önemine değinilecektir. Katılım bankacılığında Türkiye'deki mevcut duruma kısaca değindikten sonra katılım bankacılığının gelişmesi için öneriler verilecektir.

\section{1. İş Dünyasındaki Temel Paydaşlar}

İnsan başlangıçta doğada, doğa koşullarının belirlediği sınırlar içerisinde varolmuştur. Ancak insan, doğa ile diğer canlılar gibi uyum içerisinde devam eden ilişkisini, zamanla doğayı kontrol etme, onu kullanmayı da içeren hâkimiyet ilişkisine dönüştürmek istemiştir. İnsan, kendini doğanın ve tüm canlıların üstünde, canlı ve cansız varlıkların hepsinin hâkimi olduğu fikri ve pratiği ile beslenmiş̧tir, Bu ön kabulü günlük hayatının merkezine de yerleştirmiştir. Sanayileşme ile birlikte bu anlayış kapitalizmin mantığg ile örtüşmüştür (Şiriner Önver, M ve Şirin Pınarcıoğlu, N, 2018: 244).

$\mathrm{Bu}$ anlayış, gezegenin ve insanlığın geleceğini, iktisadi faaliyetlerin sürdürülebilirliğini tehdit eden sorunların temelini oluşturmaktadır. Özellikle şirketlerin üretim yaparken görmezden gelinen negatif dışsallıklar sonucunda bozulan doğal çevre ve üretimden hak ettiği payı alamayan çalışanların yaşam koşullarının gittikçe bozulması yatmaktadır. Bu sorunlara, İsviçre'nin Davos kasabasında bu yıl 50'incisi yapılan Dünya Ekonomik Forumu'nda yayınlanan WEFORUM (2020) 
bildirisinde de değinilmiştir. Bildiride bir şirketin paydaşlarına yönelik temel davranış şekillerinin nasıl olması gerektiği belirtilmiştir. Aşağıdaki kısımlarda bu bildiriden de yararlanılmıştır.

\section{1. Şirketler}

Günümüz iş dünyasında ve herhangi bir sektörde işletmelerin amacı belirlemiş oldukları hedeflere ulaşarak performanslarını arttırmaktır. İşletmelerin sürekli gelişen ve değişen teknolojilere uyum sağlamaları ve ürünlerini veya hizmetlerini iletişim kanallarını kullanarak tüketicilere etkin bir şekilde sunmaları beklenmektedir. $\mathrm{Bu}$ değişiklikler, işletmelerin paydaş ilişkilerini dikkatli ve sorunsuz bir şekilde yönetmesi gerektiğini ortaya koymaktadır. Temel olarak, çalışanların tutum ve davranışları işletmelerin performansını etkiler ve bu da tüketici davranışlarına yansır. Bir işletmedeki yönetim yapısının tek bir kararı, paydaşların yaşamlarını olumlu ya da olumsuz anlamda değiştirebilir (Adıgüzel vd., 2020: 1069). Bu yüzden şirketlerin amacı, tüm paydaşlarını ortak ve sürdürülebilir değer yaratmaya dahil etmek olmalıdır. Dolayısıyla şirketler, böyle bir değer yaratırken, sadece hissedarlarına değil, tüm (çalışanlar, tedarikçiler, müşteriler ve diğer) paydaşlarına, topluma hizmet ederken çevreyi de korumalıdırlar. Bu şekildeki yaklaşımın yani tüm paydaşların farklı çıkarlarını anlamanın ve bunları uyumlaştırmanın en iyi yolu, tüm şirketlerin bu amaca yönelik uzun vadeli politikalar oluşturması ve icra etmesi gerekir. Bu da şirketlerin maliyetlerini yükselteceği için kendi inisiyatifleriyle bu tarz faaliyetleri icra etmelerini beklemek biraz hayalcilik olacaktır. Dolayısıyla hem yerel hem de küresel ölçekteki düzenleyici ve denetleyici yapılara, şirketlerin bu amaçlar doğrultusunda çalışabilmesi için büyük görevler düşmektedir. Zira şirketlerin yaşadığı başarısızlıklar, bulaşıcılık etkisiyle çok derin olabilmektedir. Karacan ve Savcı'ya (2011: 44) göre de yöneticilerin umursamaz yaklaşımları nedeniyle, muhasebe sistemine gereken önemi vermemeleri, işletme yönetiminin planlamasını, denetimini ve değerlemesini iyi yapmamaları, çok riskli projelere eğilimli olmaları işletmeleri mali başarısızlığa itmektedir. Bu yüzden şirketlerin faaliyetlerinin denetimi için etkin yapılar kurulmalı ve işletilmeli.

\subsection{Hissedarlar}

Şirketler, hissedarlarının girişimcilik risklerinin karşılığını ve yatırımlarının devamlılı̆̆ını sağlayacak bir getiri sağlamalıdırlar ki, hem girişimcilik ruhu ödüllendirilmiş hem de yeni yatırımlara örnek olabilmiş olsunlar. Şirketlerin bu amaca yönelik çalışabilmesi için birbirlerini yıkıcı değil geliştirici rekabet şartları, düzenleyici/denetleyici otoritelerce sağlanması gerekir. Böylece hem bugünü hem de geleceği feda etmeyen sürdürülebilir kalkınma koşulları sağlanabilir. Kayıt dışı ekonomik faaliyetlere izin verilmeyeceği için kamunun gelir kaynakları da süreklilik kazanır.

\section{3. Çalışanlar}

Şirketler, çalışanlarının kuruma bağlılığını sağlamak için onlara itibar gösterildiğini hissettirecek saygıyla davranırlar. İstihdam edilen kişilerde çeşitliliği sağlarlar. Çalışma koşullarında ve çalışanların refahında sürekli iyileştirmeler için çaba gösterirler. Böylece hızlı bir değişimin yaşandığı iş dünyasında, kazan kazan felsefesine yönelik istihdamda süreklilik sağlamış olurlar.

\subsection{Tedarikçiler}

Şirketler, değer yaratmada tedarikçilerini de, kazan kazan felsefesiyle gerçek ortaklar olarak görmelidirler. Yeni piyasa katılımcılarına adil bir şans sağlamalıdırlar. Böylece ulvi bir değer olan insan haklarına saygıyı tüm tedarik zincirine entegre etmiş olurlar.

\subsection{Müşteriler ve Diğer Paydaşlar}

Şirketler, ürettiği mal ve hizmetlerle, ihtiyaçları en iyi karşılayan bir değer önerisi sunarak, üretimden müşterilerine doğru yönelen bir zincirde hizmet vermelidirler. $\mathrm{Bu}$ süreçte, serbest ve açık bir rekabet ortamındaki eşit oyun alanını kabul eder ve desteklerler. Her türlü hilekârlığa, 
yolsuzluğa yönelmeden, içinde çalıştığı ekosisteme de güven duyulmasına hizmet ederler. Müşterilerini, olumsuz etkileri veya olumsuz dışsallıkları da içeren ürün ve hizmetlerden haberdar ederler.

Şirketler, faaliyetleriyle diğer paydaşlarına veya genel ifadesiyle topluma da hizmet ederler. Bağlı oldukları toplulukları destekler ve vergi sorumluluğunu yerine getirirler. Bünyesindeki verilerin güvenliğini sağlayarak, etik ve verimli kullanılmasını sağlarlar.

\subsection{Küresel Çevre}

Şirketler, gelecek nesiller için gezegenin birer emanetçisi olarak hareket ederler. İnsanların yaşam standartlarını artırmak için bilgi, yenilik ve teknolojinin sınırlarını sürekli genişletirler. Başka bir ifadeyle şirketler, servet üreten iktisadi bir birimden daha fazlasıdır. Daha geniş sosyal sistemin bir parçası olarak insani ve toplumsal talepleri yerine getirirler. Dolayısıyla şirketlerin performansları sadece hissedarların menfaatlerinde değil, aynı zamanda çevresel, sosyal ve iyi yönetişim hedeflerine ulaşılıp/ulaşılamadığı hakkında da ölçümlenmelidir. Asillerin vekilleri olan yöneticilerin de temel görevi bu dengeyi sağlamak olmalıdır.

Yaşadığımız gezegenin küresel bir köy haline gelmesi çok uluslu şirketlerin faaliyetlerini, hizmetlerini bu doğal çevrede yaşayan tüm paydaşlara hizmet etmek olarak belirlemesi gerekir. Bunun için de şirketler yanında tüm ulusal yönetimler, hükümetler (gerçekleşmesi çok zor olan) birlikte hareket etme becerisini gösterebilmelidirler ki, küresel geleceğimiz riske atılmasın.

Özetle, küresel ölçekte kurumsal veya bireysel vatandaşlık bilincinin gerçekleşebilmesi için şirketlerin, (dünyanın durumunu iyileştirmek, sürdürülebilir kalkınmayı gerçekleştirebilmek için) diğer şirketlerle ve paydaşlarla işbirliği içinde temel becerilerin, yetkinliklerin, girişimcilik gibi özelliklerin gelişmesi için çalışmaları, kaynakları kullanmaları teşvik edilmelidir. Bunun için de yerel ve küresel ölçekte düzenleyici ve denetleyici kurumların etkin çalışması gerekmektedir.

\section{Paydaşlar Arasındaki İliş̧kilerin Koordine Edilmesinde Düzenleyici ve Denetleyici Kurumların Önemi}

Kapitalist üretim tarzının akıbetini şu andan bilmek biraz zor olmakla birlikte bugün için varlığını genişleme, daralma ve krizlerle sürdürdüğü bir gerçekliktir (Öztürk \& Akdağ, 2017: 158). $\mathrm{Bu}$ yüzden devletin gerekli düzenlemeleri yapmadığı ve çalıştırmadığı ortamlarda şirketlerin de paydaşlar kapitalizmine yönelmesinin mümkün olmadığını edinilen tecrübeler göstermektedir. Dolayısıyla yaşadığımız gezegende her açıdan gelinen durum, sürdürülebilir ve uyumlu bir dünyaya veya paydaşlar kapitalizminin amaçlarına ulaşılabilmesi için hem yerel hem de küresel ölçekte düzenleyici ve denetleyici kurumların etkin çalışmasına ihtiyaç olduğunu ispatlamaktadır. Zira yaşanılan tecrübeler göstermektedir ki, her ölçekteki yapıda, gerekli özendirici düzenlemelerin yapılmadığı ve yaptırımların olmadığı ortamda, şirketlerin, paydaşlar kapitalizmini tercihe yönelmesi kolay olmayacaktır. Bu yüzden sistemdeki dönüşümün sağlanabilmesi için temel koşullar Acemoğlu ve Robinson'a (2016: 407) göre mülkiyet haklarını hayata geçiren, eşit rekabet koşulları sağlayan ve yeni teknoloji ve becerilere yatırım yapmayı motive eden kapsayıcı ekonomik kurumlar olmalıdir.

Naqvi’ye (2019: 212) göre de gönüllü bireysel davranış, başlı başına sosyal refahı azami seviyeye çıkaramaz ve aktivist bir kamu politikası tarafından desteklenmesi gerekmektedir. Başka bir deyişle ahlak değerleri, bireysel davranışlar ve kamu politikasının her ikisine de yansıtılmak mecburiyetindedir.

$\mathrm{Bu}$ amaçlara kamu eliyle ulaşılmasını sağlayacak yapının günümüzdeki genel şekli bağımsız düzenleyici ve denetleyici kurumlardır. Bu kurumların sahip olduğu otorite sayesinde, hem işletmeler hem de onların paydaşlarının tüm haklarının tanınması ve korunması teminat altına alınacaktır. Bunların oluşturulup, çalıştırılmadığı durumda "piyasalar, katılımcıların yolsuzluk ya da rekabet karşıtı eylemler içerisine girmesiyle; işlem maliyetlerinin, teknolojik ve diğer parasal 
olmayan dışsallıkların içselleştirilmesini engellemesiyle; asimetrik bilginin etik tehlikeler ve olumsuz seçimlere yol açması durumuyla çöker" (Rodrick, 2014: 41).

$\mathrm{Bu}$ gibi olumsuzlukların yaşanmaması için özel ve kamu sektöründe, hizmet arzından mamul geliştirmeye; ticari faaliyetlerin veya kamu hizmetlerinin düzenlenmesinden denetlenmesine kadar; günlük yaşama ait her alanda uygulanabilecek bir fikir, davranış ve iş yapma şekli için sistemi düzenleyebilecek otorite olarak, bağımsız düzenleyici, denetleyici kurumların yapılandırılması ve çalıştııılması gerekir. Er (2011: 324) çalışmasına göre de ekonomide önemli aracılık fonksiyonu yanında yapısal olarak kırılgan olan ve bilgi asimetrisinin etkisi ile piyasa başarısızlıklarının kolayca yaşanarak, krize dönüştüğü finansal piyasaların kamu tarafından düzenlenmiş bir yapıda ve yine kamunun gözetiminde/denetiminde faaliyetlerini yürütmesi tüm dünyada yaygınlık kazanan ve uygulanan bir model olmuştur.

\subsection{Piyasaların Düzenlenmesi ve Denetiminde Kurumsal Yönetimin Önemi}

Piyasaların, bağımsız düzenleyici, denetleyici kurumlar tarafından takibi yanında yine bu kurumlar aracılığıyla, işletmelerin kalite yönetim sistemlerini kurması ve çalıştırması sağlanmalıdır. Çünkü bütün ekonomik yapılar için çok önemli olan kurumsallaşmanın başarılamadığı bir durumda risklerin yönetilemez hale gelmesi, mikro ölçekte işletmelerin başarısız olma riskini artırmaktadır. Makro boyutta da fiziksel, finansal sermayenin israf edilmesine yol açmaktadır. Çözüm; bağımsız düzenleyici ve denetleyici kurumlar aracılığıyla, kurumsallaşmanın da önemli bir adımı olan iş yapma süreçlerinin tanımlanmasını içeren uluslararası standartların tüm işletmelerde kurulması ve işletilebilmesi de sağlanmalıdır ki, kurumsal yönetimde başarı sağlanabilsin.

Millstein'e (2020) göre de kurumsal yönetim; bir şirketin, hak sahipleri ve kamuoyunun menfaatlerine zarar vermeyecek şekilde, finansal ve insan kaynaklarını kendine çekmesini, verimli çalışmasını ve hissedarları için uzun dönemde ekonomik kazanç elde ederek istikrar sağlamasını mümkün kılan kanun, yönetmelik ve gönüllü özel sektör uygulamalarının bileşimidir.

Uygulamaların gönüllülük boyutu istisnai bir durum olacağı için piyasaların, bağımsız düzenleyici, denetleyici kurumlar tarafindan düzenlenmesi ve denetlenmesi gerekmektedir. Tabii ki, bunun yanında yine bu kurumlar tarafından, işletmelerin uluslararası kalite yönetim sistemlerini kurmasının sağlanması (gerekiyorsa bu yönde teşvikler verilmesi) kurumsal yönetimde önemli bir adım olabilecektir. Çünkü bütün iktisadi birimler için önemli olan kurumsallaşmanın başarılamadığ 1 bir durumda risklerin yönetilemez hale gelmesi, hem işletmelerin hem de paydaşlarının başarısız olma, olumsuz etkilenme riskini artırmaktadır. $\mathrm{Bu}$ nedenle, bağımsız düzenleyici ve denetleyici kurumların etkin çalışması yanında; iş yapma süreçlerinin uluslararası düzenlemeleri olan Uluslararası Standardizasyon Örgütü-International Organization for Standardization (ISO) standartlarına uyumun tüm işletmelerde gerçekleştirilmesi, sistemlerinin kurulması sağlanmalı ve çalıştırılmalıdır. Böylece kurumsal yönetim anlayışının; adillik, şeffaflık, hesap verebilirlik ve sorumluluk ilkeleri ${ }^{1}$ hayata geçirilebilir.

İşletmelerin, kuruluş ve faaliyet süreçlerinin düzenlenmesini ve denetlenmesini sağlayacak çeşitli ISO standartlarının kurulması ve işletilmesinin sağlanması yanında; iç ve dış denetime açık olmaları da; hem sistemik hem de sistemik olmayan risk yönetiminde başarısızlığı azaltacaktır. Fakat kurumsallaşmanın gerektirdiği temel yapıların kurulamaması veya etkin çalıştırılamaması durumunda özellikle sistemik risklerin yönetilmesi zorlaşmaktadır. Hatta karşılaşılan risklerin

1 Türkiye Kurumsal Yönetim Derneği (TKYD, 2020) göre kurumsal yönetim ilkeleri: I- Adillik (pay sahiplerine eşit mesafede olma, işlevsel azınlık hakları). II- Şeffaflık, III- Hesap Verebilirlik (şirket malvarlıklarının korunması, pay sahiplerinin ve diğer menfaat sahiplerinin haklarının dengelenmesi). IVSorumluluk (şirketlerin hissedarları için değer üretirken toplumsal değerleri gözeten kanun ve düzenlemelere uygun bir şekilde faaliyet göstermesi). 
etkileri, bulaşıcılık nedeniyle daha da derinleşmektedir. Çünkü risklerin yönetimi, gerek finansal sektör gerekse de işletmeler için gittikçe zorlaşmaktadır. Bu yüzden ilgili sektörlerdeki düzenleyici ve denetleyici kurumlara önemli görevler düşmektedir.

$\mathrm{Bu}$ süreçlerin, yapıların kurulması ve işletilmesinin olmazsa olmaz unsuru olan çalışanlar özellikle üst yöneticiler de çok önemlidir. Hissedarların/asillerin vekilleri olan yöneticilerin bu bilinçle çalışmaları, aralarındaki vekâlet çatışmaları önlenmelidir. Yani vekillerin tüm paydaşlar arasındaki dengeleri sağlayabilecek şekilde çalışmaları sağlanmalıdır. Bunun için bu dengeyi sağlayabilecek kurumsallaşma seviyelerinin de tesis edilmesi ve işletilmesi gerekir.

\subsection{Vekâlet Çatışmalarının Önlenebilmesinde Kurumsal Yönetimin Önemi}

İşletmelerin kuruluş ve faaliyet süreçlerinin düzenlenmesini ve denetlenmesini sağlayacak ISO gibi standartlar yanında; işletmelerin standart şekle getirilmiş finansal muhasebe ve raporlama sistemlerini kurması ve işletilmesi de gerekmektedir. Bunun için de temel şart, tüm yapılarda iç ve dış kontrol süreçlerinin tanımlanması ve işletilmesi olmalıdır. Ancak bu yapıların tamamıyla kurulması ve işletilmesi durumunda da işletmeler, çeşitli risklerle karşı karşıya kalacaklardır. Bunlardan birisi de, gerek kurumsallaşmış gerekse de kurumsallaşmamış yapılarda karşılaşılacak olan, asil/vekil (The principal-agent problem) ilişkisinden kaynaklanan vekâlet çatışmasıdır.

Saraç'a (2017: 171) göre bir vekâlet ilişkisi, bir ya da birden fazla kişinin (müvekkil), diğer kişileri (vekil), bir hizmeti gerçekleştirebilmeleri için istihdam etmeleri ve bu vekillere karar verme yetkisini devretmeleriyle oluşur. Finansal yönetimde en önemli vekâlet ilişkisi, hissedarlar ile yöneticileri ve borç verenler ile hissedarlar arasında olduğu kabul edilmektedir.

Bir vekâlet ilişkisinde ortaya çıkması muhtemel çatışmanın temel nedeni, taraflar (asil/sahip/hissedar ile vekil/çalışan yönetici/borç veren) arasındaki çıkar çatışmasıdır. Örneğin, yöneticilerin (vekil), işletme faaliyetleri hakkında hissedarlardan (asil) daha fazla bilgiye sahip olması nedeniyle, olumsuz bir şeyi gizleme veya olmayan bir şeyi varmış gibi gösterebilmeleri mümkündür. Başka bir ifadeyle, yöneticiler, kişisel çıkarlarının peşinden gitmenin yanı sıra, kişisel güçlerini artıran ancak kurumun karlılı̆̆ını artırmayan, işletmenin geleceğini riske atan kurumsal stratejiler de uygulayabilirler. Bu durum da firma sahiplerinin, daha geniş bir bakışla paydaşların; yöneticilerin, neler yaptıkları hakkında tam bilgi sahibi olmaya, israf harcamalarını veya sahtekârlıklarını nasıl önleyebilecekleri konusunda arayışa itecektir.

Hissedarların, bu ahlaki tehlike sorununu azaltmalarının bir yolu, işletme faaliyetleri hakkında bilgi üretim süreçlerini kurmaları ve/veya bu konuda dışarıdan hizmet almalarıyla firmanın faaliyetlerinin izlenmesidir. İşletmenin sık sık denetlenmesi ve yönetimin ne yaptığının kontrol edilmesinin tabii ki önemli bir maliyeti olacaktır. Fakat bu işlemler ahlaki tehlike (asil/vekil) sorununu azaltacaktır. Mishkin'e (2007) göre, asimetrik bilgiden, asil/vekil ilişkisinden kaynaklanacak sorunların önlenmesinde standartlaştırılmış finansal muhasebe ve raporlama sistemlerinin kurulması ve işletilmesi gereklidir. Hatta küresel sermaye yatırımlarının arttığı günümüzde, muhasebe bilgi sisteminin ürettiği finansal karakterli bilgilerin uluslararası muhasebe standartlarıyla uyumlaştırılması, dış denetim faaliyetlerini de kolaylaştıracaktır. Bu konuda Kamu Gözetimi Muhasebe ve Denetim Standartları Kurumunun düzenleyici ve denetleyici faaliyetleri de çok önemlidir ve her geçen gün gelişmektedir².

Özetle, işletmelerin Uluslararası Finansal Raporlama Standartlarını uygulamasının yaygınlaştırılabilmesi durumunda, ekonomide hem kayıt dışı faaliyetler önlenebilecek hem de

\footnotetext{
${ }^{2}$ KGK ile İslami Finans Kuruluşları Muhasebe ve Denetim Kuruluşu (AAOIFI) arasında da, faizsiz finans sektörüne ilişkin muhasebe, denetim, etik ve yönetişim standartlarının sisteme kazandırılması amacıyla bir telif anlaşması imzalanmıştır. Bu anlaşmayla, faizsiz finans kurumlarının finansal tablolarının, faizsiz finans muhasebe standartları ile Fikhî ilke ve kurallara uygun olarak doğru ve gerçeğe uygun bir görünüm sağlayıp sağlamadığı konusunda kullanıcılara bir güvence verilmesi hedeflenmektedir (KGK, 2020).
} 
işletmelerin finansal raporları tam olarak düzenlenebilecektir. Böylece hem borç verenler hem de tüm paydaşlar, işletmelerin kredi değerliliği, geleceği hakkında daha gerçekçi ölçümleme yapabilecek, risk yönetimi daha kolay gerçekleşebilecektir.

\section{3. İslam İktisadının Kurumsal Yönetim ve Vekâlet Sorununa Bakışı}

İslam'daki yönetim sistemini anlamanın en iyi yolu, bu konuya; bireyin, toplumun ve devletin haklarını düzenleyen ilkeler, mülkiyet ve sözleşmeler hukuku ışığında bakmaktır. Tabii İslam'ın hakların tanınması ve korunması konusundaki kapsamı sadece insanla sinırlı değildir, her türlü canlı türünü ve çevreyi de içine alır. Her yaratılana belirli haklar verilmiştir ve her yaratılan diğerlerinin haklarına riayet etmek zorundadır. Bu haklar insanların hesap vereceği sorumlulukları da beraberinde getirir. Saraç'in (2017: 190) belirttiği bu asgari ama mükemmel beklentiler maalesef varsayımsal bir durum gibi kalmaktadır. Bu yüzden piyasaların düzenlenmesi ve denetlenmesinden sorumlu kurumlar, bu çerçeveye göre şirketlerde kurumsal yönetimin gerçekleşmesi için azami hassasiyeti göstermelidir.

Bu hassasiyetin ve tüm taraflar arasında adaletin sağlanması Saraç'a (2017: 194) göre İslami çerçevedeki ticari sözleşmelerin en temel üstünlüğüdür. Konvansiyonel bağlamda işletme organizasyonunda veya üretim sürecinde bilgi asimetrisi veya ahlaki zarar durumundan dolay1 maruz kalınan sahip/vekil sorunu, İslami sözleşme türlerinde minimize edilmiş olmaktadır. İslami firma teorisinde, firmanın sadece sahiplerinin değil tüm paydaşların menfaatini gözeterek, kendisine emanet edilmiş sermayeyi en etkin ve verimli biçimde kullanmak için tüm gücünü kullanacağı varsayılır. Şura yöntemiyle üretim planlaması yapılırken ihtiyaçların hiyerarşisi dikkate alınır. Vekil, dürüstlüğüne ve yetkinliğine göre ödüllendirilir. Ticari sözleşmelerin İslam hukukunun rehberliğinde tasarlanması ve uygulanması durumunda sahip-vekil sorunu minimize edilmiş olur ve böylece firmaların kar etme motivasyonundan toplumun tüm kesimleri fayda sağlar.

Sahip/vekil ilişkisinin katılım bankacılığında uygulamaya aktarılmış ve daha da geliştirilmesi gereken şekli emek/sermaye ortaklığıdır. Bu uygulamanın geliştirilmesi katılım bankacılığı sistemine derinlik katacaktır. Bu yöntemlere sonraki alt başlıklarda değinilecektir.

\section{Paydaşlar Kapitalizmine İslam'ın Bakışı}

Yanlış hak anlayışına sahip olan kuvveti üstün tutan dünya görüşüne göre kaynaklar kıttır ve kıt olan kaynaklardan faydasını maksimize etmek isteyen insanlar arasında mücadele kaçınılmazdır. Bu mücadele kendisini kapitalist sistemde çıkar çatışması kapsamında gösterirken, sosyalist sistemde sınıf çatışması şeklinde göstermektedir. Doğru hak anlayışına dayanan, Hakkı üstün tutan dünya görüşüne göre ise; dengeli olan kaynaklar arasında insanların ihtiyaçları doğrultusunda çıkar paralelliği kuracakları, karşılaştıkları sorunları ortaklıklar kurarak çözecekleri ifade edilmektedir (Öztürk, 2017: 149).

Bu yaklaşıma sahip olan "paydaşlar kapitalizminde tek amaç şirketlerin kârlılı̆̆ını artırmak olmamalıdır. Şirketler, gelirlerini, katkıları ölçüsünde çalışanlarla, tedarik zincirinde yer alanlarla, müşterileriyle ve üretim sürecindeki bütün aktörlerle paylaşırken; sosyal ve çevresel boyutu da dikkate alarak faaliyetlerinin kâr/zarar hesabını yapmalıdırlar. Böylece İslamiyet'in "temel amacı olan, insanlar arasında sürdürülebilir bir iktisadi hayatın hakkaniyetli bir biçimde yürütülmesi" mümkün olsun” (Abdullahoğlu, 2014: 21).

Paydaşlar kapitalizmi öncesinde egemen görüş olan hissedarlar ve devlet kapitalizminin neden olacağı sorunlar orta çıkmadan önce Kur'an-1 Kerim bunlara yer vermiştir. Naqvi'ye (2019: 199) göre Batı'daki kapitalist büyümeyi motive etmiş gibi görünen dini ahlaki değerler, mesela; doğruluk, kamusal işlemlerde dürüstlük, sözleşmelerin kabulü, Kur'an-1 Kerim'de de çeşitli yerlerde oldukça açık olarak vurgulanmaktadır. 
Paydaşlar kapitalizminin gelir ve servet dağılımında adaleti sağlamak amacına İslam bunun nasıl sağlanacağı konusundaki özgün (faizin haram olması, zekât, fitre vb.) araçlarıyla da zaten sistemin temelini inşa etmişti. Gelir ve servet dağılımında adaletin nasıl sağlanacağı konusunda İslam'ın bakışını Naqvi (2019: 200) şu şekilde ifade etmiştir: (a) Özel mülkiyet hakkı ne mutlak ne de sınırsızdır fakat Allah'ın tüm servetin sahibi olması ile ilgilidir ve bu sebepten dolayı fakirlerin zengin kimselerin servetlerinde bir payı vardır. (b) Esasen vekil olan insan, sahip olduğu servetle ne canının istediğini yapmak ne de onu istiflemek konusunda tamamıla özgür değildir. (c) Servetin birkaç kişinin elinde yoğunlaşması, istenmeyen ve ahlak dışı bir durumdur. (d) İnsanların servet kazanımında eşitsizlik olabilmesine rağmen servetin kullanımında insanlar eşittir.

Başka bir ifadeyle, İslam'a göre insanlar arasında mutlak bir eşitlik olmasa da, bu durum servetin adil veya yeniden dağıtımına engel değildir. Çünkü Naqvi’ye (2019: 201) göre: (a) Fakirlerin zenginlerin serveti üzerinde hakkı vardır bu da zenginin özel mülk üzerinde haklarının mutlak ve sınırsız olmadığını ima eder. (b) Verme eylemi bu sebepten fakirlere aslında ilk başta kendilerine ait olanı iade anlamına gelir ki bu da fakirlere vermenin, hayırseverlik değil adalet eylemi olduğunu kasteder. (c) Fakirlere yardım; (zengin) bireylere yavaş yavaş sosyal fayda için çalışma -yani verme eylemi, kendilerinin servetinden bir kesinti yapılması anlamına gelse biletaahhüdü zerk eden ruhsal mutluluğa ulaşmanın en önemli aracıdır. Ve (d) fakirlere vermeme (yani fakirlerin ihtiyacını ihmal ederek, biriktirme ve/veya lükse fazlasıyla harcama yapma) kişinin inancı reddetmesi anlamına gelir. Bir karşılaştırma meselesi olarak fakirliğin azaltılması konusundaki İslami ahlak değerleri, bireyleri ortak fayda için çalışmaya diğer ahlak sistemlerinden daha fazla özveriyle motive eder.

\section{1. İslami Bakışla Paydaşlar Kapitalizmine Yönelik Temel Stratejilerin Belirlenmesi}

Paydaşlar kapitalizminin amaçlarına ulaşılmasını sağlayacak iktisadi yapının ve onun önemli bir unsuru olan şirketlerin çalışma şartlarını düzenleyecek stratejilerin yeniden belirlenmesi gerekir. Chapra'ya (2018: 227) göre de kapitalizmden de sosyalizmden de farklı olarak, İslam'ın hedeflerinin yine İslam'ın temelini oluşturan felsefenin mutlak ve mantıksal sonuçları olduğu aşikârdır. Toplumdaki farklı grupların ve sınıfların arasındaki hayatta kalma ve iktidar mücadelesinden kaynaklanan birbiriyle uyumsuz unsurların bir araya gelerek oluşturdukları karışık ve düzensiz bir resim söz konusu değildir. Bu hedeflerin gerçekleştirilmesi İslami sistemin o kadar temel bir parçasını oluşturur ki, Müslüman bir toplumun, İslam'a ne derece uygun olduğunun belirlenmesi için gerekli kriterleri teşkil eder. Elbette bu hedeflerin dünya görüşüyle uyumlu olması yeterli değildir. İslam'ın temel felsefesinin mantıksal bir sonucu olan ve eğer ciddi bir şekilde uygulamaya konursa Müslüman bir toplumun hedeflerini gerçekleştirmesini sağlayacak bir strateji geliştirmek de zorunludur. İslam böyle bir stratejiye sahiptir. Bu strateji, tüm ekonomik sistemin, hepsi vazgeçilmez olan ve birbirini besleyen dört unsura bağlı olarak yeniden organize edilmesinden oluşur:

- Toplumsal olarak kabul edilmiş ortak bir filtre mekanizması: İslam'ın emirlerini de esas alan bağımsız düzenleyici ve denetleyici kurumlar aracılığıyla bu mekanizma sağlanır.

- Bireylerin hem kendi çıkarları hem de toplumsal çıkarlar için ellerinden gelenin en iyisini ortaya koymasını sağlayacak bir teşvik sistemi: Bunun için tüm bireylerin istihdam edildiği şirketlerin kurumsallaşması teşvikler aracılığıyla sağlanmalı ki, şirketlerin verimli çalışması; tüm paydaşların haklarını alması mümkün olsun. Şirketler arasında yıkıcı rekabet oluşmamasını, verimli çalışmasını sağlayacak sistemin temel şartları üçüncü maddede açıklanmaktadır.

- Tüm ekonominin, sahip olunan kısıtlı kaynaklara karşın amacın gerçekleştirilmesini sağlayacak şekilde yeniden yapılandırılması: Şirketler arasında yıkıcı rekabet ve kayıt dışı faaliyet olmadan sağlanacak çalışma şartları, kuruluş izinlerinin verilmesinde aranmalıdır. Sonrasındaki performans ölçümlemeleriyle; dış denetimlerle bunların sürekliliği sağlanmalıdır. Böylece şirketler arasında yıkıcı rekabet sonucu iflaslar oluşmasının zincirleme etkileri yani kısıtlı kaynakların israfı 
önlenmiş olacaktır. Bankaların verdiği finansmanların geri dönmeme olasıllığı; ortak olduğu projelerin başarısızlık riski de azalacaktır.

Bunun için günümüzün küresel ticaret savaşlarının yaşandığı ortamda, Küçük ve Orta Büyüklükteki İşletmeler (KOBİ) faaliyetlerinin başarısının artırılması maksadıyla gerekli düzenlenme ve denetlemeleri sağlayacak kurullara ihtiyaç vardır. Bu amaçla On Birinci Kalkınma Planı da (2019), sürdürülebilir kalkınma amaçlarının takip ve gözden geçirilmesi için iyi işleyen ve katılımcı bir kurumsal koordinasyon mekanizması kurulacağını belirtmektedir. Plan, sürdürülebilir kalkınma amaçlarının uygulanmasının ulusal düzeyde takip ve gözden geçirilmesiyle; koordinasyonunu sağlamak üzere Strateji ve Bütçe Başkanlığı başkanlığında, ilgili kamu kurumlarının yanı sıra yerel yönetimler, akademi, özel sektör ve Sivil Toplum Kuruluşu (STK) temsilcilerinin katılımı için esnek bir yapıda Ulusal Sürdürülebilir Kalkınma Koordinasyon Kurulu kurulacağını belirtmektedir.

\subsection{Temel Strateji: Kurulların Oluşturulması ve İşletilmesi}

Paydaşlar kapitalizmine yönelik belirlenen temel stratejilerde başarıya ulaşılabilmesi için bağımsız düzenleyici ve denetleyici kurumların etkin çalışması ve ISO'nun yayınladığı standartların, şirketlerde kurulması ve işletilmesini (Ulusal Sürdürülebilir Kalkınma Koordinasyon Kurulu bünyesinde) sağlayacak yerel kurulların oluşturulması gerekmektedir.

Bu kurullar, şirketlerin, kuruluş aşamasındaki yeterliliklerinin var olup olmadığını kontrol edecek ve bunların sürekliliğini sağlayacak düzenlemelerle kurumsallaşma seviyelerinin artırılmasını sağlayacaktırlar. Bu şekildeki yapılanma sayesinde tüm paydaşların katkıları ölçüsünde paylarını alacağı bir iktisadi yapıda çalışacak şirket faaliyetlerine izin verilmiş olacaktır. Böylece hem şirket faaliyetlerinin sürdürülebilir bir şekil alması; hem de ülke kaynaklarının heba edilmeden sürdürülebilir kalkınma hedeflerine ulaşılması mümkün olabilecektir. Çünkü işin başında, şirketlerin tüm süreçlerinin tanımlanması, risk analizlerinin yapılması; hem faaliyetlerinin standart bir şekilde icrasına hem de operasyonlarının neye göre kontrol edilebileceğine, sistemin sürekli dış denetim ve iyileştirmelere açık olmasına hizmet edebilecektir. Dolayısıyla, devamlı yapılan dış denetimler sonucunda, ortaya çıkan neticelerin baştaki standartlar ile karşılaştırılarak kontrol edilebilmesi, varsa sapmalarının ölçülebilmesi sayesinde mükemmele ulaşabilmek kolaylaşacaktır.

Kısacas1 bu standartlar sayesinde, şirket faaliyetlerinin gerektirdiği süreçlerin performanslarının ölçülebilir, şeffaf olması sağlanabilecektir. Zira küresel ve ulusal ölçekte mal ve hizmet üretilebilmesi; sürdürülebilir kalkınmada başarı sağlanabilmesi için de bu standartlar, üretimden tüketime olan zincirindeki tüm taraflar arasındaki bilgi asimetrisini, vekâlet çatışmaları gibi çeşitli engelleri aşmaya da yardımcı olabilecektir. Şirketlerin sahip olacağı bu yeterlilikler; hem fiziksel, finansal sermayeyi hem de paydaşlar arasında adil dağılımı sağlayarak; üretimden tüketime kadar gerçekleşen bütün faaliyetlerin ekosistemle uyumlu bir şekilde gerçekleşmesini ifade eden sürdürülebilir kalkınma hedeflerine ulaşlabilmeye imkân verebilecektir.

- Devlete hedeflerin sağlanmasına yönelik olumlu ve güçlü bir rol verilmesi: Güçlü bir devlet, sahip olduğu otorite ile ülkenin yeniden yapılanmasını sağlayacak, siyasal sistemden bağımsız; herkesi kapsayan; saydam ve hesap verebilen; oyunun kurallarını koyan ve denetleyen bir sistemi inşa etmesi gerekir. Böylece devlet, ekonomik ve sosyal yaşama ait sistemin rasyonelleştirilebilmesini; kurumsallaşma ilkelerinin uygulanabilmesini; piyasa aksaklıklarının giderilebilmesini; yasa dışı, kayıt dışı ekonomik faaliyetlerin ortadan kaldırılabilmesini; piyasaların popülist müdahalelerden kurtarılabilmesini sağlayabilsin. Demir'e (2013: 115-116) göre güçlü bir ekonomik sistem için aşağıdaki düzenlemelerin devlet tarafından yapılması gerekmektedir:

1. Her türlü mülkiyet haklarının tanımlanmasını, belirlenmesini ve korunmasını sağlayan bir hukuki sistem kurulması. 
2. Sözleşme gereklerinin yerine getirilmesi sağlayacak mekanizmaların oluşturulması.

3. Tekelleşmeleri önleyecek rekabet sisteminin kurulması.

4. Tüketicilerin haklarını koruyacak bir tüketici koruma sistemi.

5. Değer saklama işlevini yerine getirebilecek bir para ve finansal sistem için gerekli ekonomik yapıyı kurmak.

6. Çalışma hayatına ilişkin etkin bir iş sağlığı ve güvenlik sistemini kurmak ve işletmek.

Oktar ve Dalyancı da (2010: 18) çalışmasında şu önerilerde bulunmaktadır: Başta ekonominin küresel teknolojik rekabet gücünün artırılmasını sağlamak üzere, iç ve dış finansman açığının kapatılması; ara malı ve teknolojide bağımlılı̆̆ın azaltılması; ticari ve finansal uluslararası serbestleşmenin etkin bir şekilde yönetilmesi; finansal sistemin, kurumsal kapasitesinin geliştirilmesi ve etkinliğinin sağlanması; özellikle finansal piyasalarda manipülasyonlar ve yıkıcı spekülasyonların önlenmesi, para, maliye ve döviz kuru politikalarında etkinliğin artırılması; finansal istikrarın sağlanması açısından önem taşımaktadır.

\section{Paydaşlar Arasındaki İlişsilerin Koordine Edilmesinde Finansal Sistemin Önemi}

İslam dininin temelinde "herkesin yararını gerçekleștirme" hedefi bulunur. Bu amaca ulaş11ırken adaletle hareket edilir. İslam ekonomisi İslam dininin değer yargıları ve ahlaki kuralları çerçevesinde maddi kaynakların elde edilmesinde ve kullanılmasında adaletli davranılarak refah artışının sağlanması için önce Allah'a sonra da topluma karşı olan görevlerin yerine getirilmesini sağlayan bir sistem olarak karşımıza çıkar (Eroğlu \& Kangal, 2016: 327). Şüphesiz bu yaklaşımın yaşamın her alanında uygulanması gerekir. Finansal sistemin de böyle bir etki gücü olduğu için faizin yasaklanması, hem finansal sistemin önemini; hem de nasıl düzenlenmesi gerektiğinin temel reçetesini vermiştir.

Chapra'ya (2018: 211) göre para ve bankacıllk sistemi, modern zaman ekonomileri üzerinde öyle muazzam bir etkiye sahiptir ki, hiçbir ekonomik sistem onun desteği olmadan sağlıklı kalamaz ve canlılığını sürdüremez ya da sosyo/ekonomik hedeflerini gerçekleştirebilmek için ciddi bir adım atamaz. Bu nedenle para ve bankacılık sisteminin, nihayetinde herkesin zarar görmesine neden olan eşitsizlikleri, gösterişçi tüketimi, işsizliği ve sağlıksız parasal genişlemeyi artıran aşırılıklardan ve dengesizliklerden sakınacak şekilde sslah edilmesi gerekmektedir. Genel olarak ihtiyaçların karşılanmasını, yüksek istihdam oranlarını ve üretim araçları üzerinde geniş tabanlı mülkiyeti teşvik eden bir sistem olmalıdır.

Uludağ ve Arıcan'a (1999: 112) göre de finansal sistem, genellikle gelişmiş ekonomilerde kurumların ve pazarların birbirlerini etkileyen fonksiyonlarını yerine getirmek amaciyla oluşturulmaktadır. Böylece, ekonomideki kurumlar ve pazarlar birbirlerini tamamlamış olur. Zaten finans sisteminin ekonomide koordinasyon görevi yapması buna dayanır. Dolayısıla, bir ekonomide finansal alt yapının oluşturulması için özel sektör finans kurumlarının teşvik edilmesi, yatırım fonlarının yeniden yapılandırılması, finansal aracıların desteklenmesi, finansal piyasaların ve finansal kurumların iyileştirilmesi gerekir. Günal'a (2010: 199) göre de bankalar, hem mali kesim hem de ekonominin geneli açısından çok önemli olduğu için bankacılık sektöründeki sorunlar ve krizler de ekonominin geneline çok çabuk yayılabilmektedir.

\section{Bankacılığı}

4.1. Paydaşlar Kapitalizmine Yönelik Finansal Sistemde Temel Strateji: Katılım

Geleneksel bankaların araç olarak kullandığı faiz dışında diğer önemli bir sorun da yaklaşımlarının anlık olmasıdır. Yani neredeyse günlük değişimleri kredilendirme ve fiyatlandırma politikalarına yansıtmaktadırlar. Dolayısıyla finansal sistemden beklenen gerçek aracilık faaliyetleri gerçekleşememektedir. Örneğin, piyasalardaki beklentilerin karamsarlığa dönüşmesiyle, bu bankaların gösterdiği panik davranışlarla, kredileri geri çağırmaları, rotatif kredi faiz oranlarını 
hızlı bir şekilde yukarı doğru güncellemeleri gibi uygulamalar şirketlerin başarısızlığında geleneksel bankacılığın hatasının büyüklüğünü göstermektedir. Başka bir ifadeyle piyasaların iyi olduğu zamanlarda (güneşli havalarda) faizli çalışan bankaların verdiği kredileri (şemsiyeleri) geri çağırma uygulamaları, şirketlerin finansal başarısızlığını ve/veya iflas riskini artırmaktadır. Aslında bu olumsuzluk yine bankaların kendilerine dönmektedir. Çünkü şirketlerin gerçek skorları ortaya çıkarılmadan tahsis edilen kredi limitleri ve projenin detaylandırılmadan yapılan kredi kullandırımları piyasalar kötüye gittiğinde bu durum "verilen kredilerin takibe düşme oranını artırmakta ve bankaların istikrarlı bir şekilde faaliyetlerini sürdürebilmelerini engellemektedir. Önemli miktarlara ulaşan takipteki krediler doğrudan finans sektörünü ve dolaylı olarak da reel sektörü olumsuz yönde etkilemektedir" (Altıntaş, 2012: 4).

$\mathrm{Bu}$ anlayışın olmadığı katılım bankacılığının ${ }^{3}$ sistemdeki etkinliği artarsa bunun ekonomideki sorunlara çözüm olmak; paydaşlar kapitalizminin amaçlarına ulaşmasına yardımcı olmak; üretimde sürekliliğin sağlanmasına gerçekten destek olmak gibi olumlu dişsallıkları görülecektir. Çünkü kar/zarar ortaklığı; emek/sermaye ortaklığı gibi yöntemleri kullanan katılım bankacılığ 1 , fon kullandırmada emek sahibi olabileceği gibi sermaye sahibi de olabilmektedir. Bu yaklaşımıyla katılım bankası, ister emek ister sermaye sahibi olsun, her durumda işin içinde, taşın altında eli olacaktır. $\mathrm{Bu}$ da onun, hem fon kullandırım öncesi hem de sonrasında sorumluluğunu artıracaktır. Yani Yazıcı'ya (2017: 126) göre projelerin seçiminde, değerlendirilmesinde riske ortak olma yaklaşımıyla değerlendirmeler, risk yönetimine yönelik analizler detaylı yapılacaktır. İşletmelerin göremeyeceği bir bakışla sürdürülen bu davranış onların kurumsallaşma seviyelerinin yükseltilmesine imkân sağlar. Çünkü mali tablolara göre yapılacak derecelendirme sürecinin firmalara kabul ettirilmesi, iş hayatında daha şeffaf bir yapının sağlanmasına, firmaların gerçeğe yakın risk düzeylerinin tespitine olanak verecektir. Bu uygulama şeklinin genelleştirilmiş olduğu finansal hizmetler sayesinde kayıt dışı ekonomi azalacak dolayısıyla kamu gelirlerinde artış sağlanabilecektir. Yani finansal sistemde sürtünmeye yol açacak vergi, harçlar gibi finansman maliyetini artırıcı unsurların kalkmış olmasının avantajları sonraki dönemlerde görülebilecektir. Kayıt dışı ekonominin azalmasıyla kamu gelirlerinin artması şeklindeki bu olumlu yansımalar sürekli olabilecektir.

Dolayısıyla paydaşlar kapitalizminin amaçlarına ulaşılmasını sağlayacak iktisadi yapı ve onu etkileyen finansal sistem, denenmiş ve paydaşlar yerine sadece sermayedarlara/hissedarlara hizmet etmiş geleneksel bankacılık yerine, faizsizlik prensibine göre çalışacak katılım bankacılığı olmalıdır. Zira Bilgili ve Demirkapı'ya (2016: 40) göre de katılım bankaları, geleneksel bankacılıkta olduğu gibi kuralsızlığı ve hukuk dışı durumları kabul etmeyip suç olduğunu söylese de buna ek olarak bu durumları günah olarak da kabul eder.

$\mathrm{Bu}$ genel bakışla katılım bankacılığı, İslam'ın gereği olarak ortaya çıksa da, yaşanan küresel finansal krizlerin nedeni olarak görülen geleneksel finansal sistemi ikame etme amaçlı olarak da görülebilmektedir. Çünkü katılım bankacılığının finansman ürünleri, öncelikle arzı teşvik etmeye yöneliktir. Fakat geleneksel bankacılı̆̆ın araçları ise belki de arz olmadan talebi şişirmeye dolayısıyla arz ve talep arasındaki dengesizlik sürecini beslemektedir. $\mathrm{Bu}$ da çeşitli şekillerde ortaya çıkan ekonomik veya finansal krizlere sebep olmaktadır. Fakat basiretli tacir olmanın gereği (ki İslam'ın emri) "kriz dönemlerinde iş adamları, ekonomik hayatın nereye doğru gittiği, yakın gelecekte nelerin olabileceği konusunda -hayallere yer vermeden- iyi hesap yapmalıdırlar. Kârın aleyhine de olsa riski aşağıya çekmeyi, ayakta durmayı marifet saymalı, emek ile anlaşarak

\footnotetext{
${ }^{3}$ Katılım kelimesi, tamamen bu kurumların çalışma mekanizmalarından türetilmiştir. Bildiğiniz gibi, katılım bankalarının temel fon sağlama yöntemi, kâr ve zarara katılım hesaplarıdır. Kâr ve zarara katılma hesapları bir anlamda hem kârın paylaşılmasını, hem ortaya çıkabilecek riskin paylaşılmasını içeren bir kavram. Nasıl ki yatırım bankaları daha çok yatırım kredisi vermelerinden kaynaklı isimle isimlendirilmişse, katılım bankalarının da kâr ve zarara katılma prensibinden türetilmeleri en makul çözümdü (Yahşi, 2013: 38).
} 
karşılıklı fedakârlıkta bulunmalı, üretim çeşidi ve pazar konusunda alternatifler aramalıdırlar (Karaman, 2012: 76)".

Krizlere sebep olan geleneksel finansman yöntemlerinde, risk paylaşım esası olmaması durumuna niçin karşı çıkıldığını Orman da (2014: 92) şu şekilde açıklamaktadır: Modern ekonomilerdeki durumun aksine, İslami bir toplumda insanların bir kısmının sadece tasarrufa yönelen, bir kısmının da sadece yatırım yapan kimseler olması istenmiyor. Herkesin şu veya bu şekilde sahip olduklarıyla ilgilenmelerini istiyor. Zira parasını faize veren kişi, parasıyla ilgisini kesmiştir. Yani dönem sonuna kadar parasıyla ilgilenmesi gerekmez çünkü vade sonunda alacağı para bellidir. Fakat parasını ortaklık ilişkisi içinde olduğu bir iktisadi işletmeye vermişse parasının geleceğiyle ilgilenmek zorundadır.

Tabakoğlu'na (2005: 137) göre de İslam, sermayenin önüne, faiz, kumar, karaborsa ve sömürü ile üretim yasağı ve israf yasağı gibi bir takım engeller koyar. Bu engellerle sermayeyi, sürekli olarak üretim içerisinde tutmaya çalışır. Çünkü sermayenin sürekli olarak üretim içerisinde tutularak, bunun adaletli bir şekilde bölüşümünü sağlamak, sosyal refahın yükseltilmesinde önemli bir araçtır. $\mathrm{Bu}$ şekilde biriken ve kullanılan sermaye, özel girişimin kontrolünde, devlet elindekinden daha etkili bir şekilde idare edilebilir. Burada önemli olan nokta, devletin, müteşebbis üzerinde etkili bir kontrol ve denetim mekanizması kurarak sisteme işlerlik kazandırmasıdır.

\subsubsection{Katılım Bankacılığında Türkiye'deki Mevcut Durum}

Türkiye'de finansal sistemdeki geleneksel bankacılığın egemen olmasının temelindeki çeşitli faktörler ve klasikleşmiş yaklaşımlar nedeniyle para piyasalarının payının yüksekliği ve finansal araçlarda da geleneksel faizli araçların ağırlıklı kullanımı göze çarpmaktadır. Bu yapıdan katılım bankacılığının büyük paylar alması kısa dönemde zor gibi gözükmektedir. Çünkü Tablo 1'de de görüldüğü gibi sistemde faiz esaslı çalışan bankaların, sektördeki mevduatların/fonların \%92'lik kısmını almasıyla ve kullandırılan kredilerde/fonlarda \%87'lik payıla mutlak bir hâkimiyeti vardır.

Tablo 1: 31.12.2020 İtibariyle Türkiye'de Faaliyette Bulunan Bankaların Payları

\begin{tabular}{cccccc}
\hline & \multicolumn{4}{c}{ Sektör Payları (\%) } & Yurt İçi \\
\cline { 2 - 4 } Bankalar & Aktifler & $\begin{array}{c}\text { Krediler/ } \\
\text { Kullandırılan } \\
\text { Fonlar }\end{array}$ & $\begin{array}{c}\text { Mevduat/ } \\
\text { Fon }\end{array}$ & $\begin{array}{c}\text { Şube } \\
\text { Sayısı }\end{array}$ & $\begin{array}{c}\text { İstihdam } \\
\text { (Bin kişi) }\end{array}$ \\
\hline Mevduat Bankaları & 87 & 87 & 92 & 10.137 & 184 \\
\hline $\begin{array}{c}\text { Kalkınma ve Yatırım } \\
\text { Bankaları }\end{array}$ & 7 & 8 & 0 & 62 & 5 \\
\hline Katılım Bankaları & 6 & 5 & 7 & 1.179 & 16 \\
\hline
\end{tabular}

Kaynak: Bankalarımız (2020) verilerinden derlenmiştir.

Fakat reformist yaklaşımlar sonucunda geliştirilecek ürünlerle katılım bankacıllı̆ııın payının artırılması mümkün olabilir. Bunun için mevzuat düzenlemeleri ${ }^{4}$ desteğiyle, hem finansal okuryazarlığın geliştirilmesi ${ }^{5}$; hem de sisteme güvenin tesis edilebilmesi gerekmektedir. Özellikle

\footnotetext{
4 Kanunlar, uygun muhasebe standartları, hedef pazar çalışması, standart hale gelmiş sözleşmelerin izlenmesi, yatırımcılara uygun finansal veri akışı ve genel olarak müşteriler için standart kalite hizmeti sunulmas1 gereklidir (Ayub, 2017: 495).

${ }^{5}$ Gelişmekte olan ülkelerde, finansal okuryazarlığın artması, hem finansal piyasaların reel ekonomik büyüme üzerindeki etkisini; hem de toplumda yoksulluğun azaltılmasında etkisi olabilir. Ayrıca, finansal okuryazar
} 
katılım bankacılığını ve sermaye piyasası araçlarını merkeze alan yeni bir stratejinin geliştirilmesi gerekmektedir. Bu stratejinin başarıya ulaşabilmesi için yukarıda önemine işaret ettiğimiz bağımsız düzenleyici ve denetleyici kurumların önderliğinde, tüm ekonomik sistemin, hepsi vazgeçilmez olan ve birbirini besleyen dört unsura bağlı olarak yeniden organize edilmesi gerekmektedir.

\subsubsection{Katılım Bankacılığının Gelişmesi İçin Öneriler}

Türkiye'de katılım bankacılığının gelişememesinin önemli bir sebebi "enflasyon, faiz, devalüasyon" sarmalının yaşanmasıdır. Turhan'a (2013: 24) göre de enflasyonun çok yüksek ve belirsiz olduğu ve reel faiz oranlarının da çok yüksek seyrettiği ortamlarda bu sistemin gelişme şansı hemen hemen yok gibi. Çünkü bu sürecin devamlı yaşanacağı beklentisi finansal sistemde uzun vadeli kaynak aktaracak yatırımcı bulmayı zorlamaktadır. Dede'ye (2017:196) göre de ticari bankalarda olduğu gibi katılım bankalarında da ortalama katılma hesabı (mevduat) vadesi 110-120 gündür. Bu yüzden "çözüm faizi yasaklamak değil, kar paylaşım sistemlerinin geliştirilerek faizin alanının daraltılması ve sonuçta ekonominin onun boyunduruğundan kurtarılmasıdır" (Özsoy, 2012: 87).

Türkiye'de enflasyonun hem düşmesi hem de enflasyon belirsizliğinin azalması, bunun sonucunda da reel faizlerin makul seviyelere gelmesi, bu sistemin gelişmesi önündeki engelleri büyük ölçüde ortadan kaldırdı (Turhan, 2013: 24). Fakat istikrarlı hale gelmemesi nedeniyle, hem ekonomi hem de finansal sistem üzerindeki tehdidi devam etmektedir. Bu yüzden tasarrufların katılım bankacılığı sistemine çekilebilmesi için enflasyona endeksli ürünlerin de devreye alınması gerekmektedir ${ }^{6}$.

Zira çeşitli nedenlerle yerel paranın, iç ve dış değerinde meydana gelecek düşüşler, onun değer saklama özelliğini olumsuz yönde etkilemektedir. Dolayısıyla Müslüman bireyler, gerek faize bulaşmama gerekse de finansal sisteme olan güvensizlikleri nedeniyle yastıkaltı tasarruflara veya para ikamesine yönelmektedirler. $\mathrm{Bu}$ durumun kısa dönemde hafifletilebilmesi için bu kesimlerin tasarruflarını, enflasyon oranlarına, döviz veya altın gibi ürünlere endeksli yatırım araçlarına, gerçekçi piyasa fiyatlamalarına bağlı yeni sistemlerin katılım bankalarınca geliştirilebilmesi gerekmektedir. Böylece hem fon talep eden yatırımcıya hem de tasarruf sahibine sunulabilecek faizsiz yeni ürünler sayesinde, katılım bankalarının ekonomi içerisindeki ağırlığı artabilecektir.

Bunun gibi önerilerin ilgili tüm taraflarca gerekli araştırmaları yapıldıktan sonra uygulamaya aktarılması gerekir. Eğri’ye (2017: 307) göre de, İslam iktisadı çalışmaları hem İslam inancına sahip olanlar hem de tüm insanlık (paydaşlar) için önem arz etmektedir. Önereceği alternatif sistem ve uygulamalarla daha adil bir iktisadi hayat ve bölüşüm sağlama potansiyeline sahiptir. Ancak, iyi niyetli ve saygıyı hak eden geçmiş çalışmalarla birlikte bu alanda yapılacak yeni araştırmalar bir vebali üzerlerinde taşıdıklarını bilmeleri gerekmektedir. İslam iktisadı çabası ve iddiası inançtan kaynaklanmaktadır ve bu öğreti Müslümanlara yaptıkları ve söyledikleri karşısında sorumluluklar yüklemektedir. Müslümanların iktisadi hayatını şekillendirecek

bireyler, piyasa koşullarını daha iyi analiz edebileceklerinden dolayı dışsal volatilite etkilerinde aşırı tepki vermeyerek, finansal piyasalardaki dalgalanmaları yumuşatabileceklerdir (OECD, 2005: 35).

${ }^{6}$ Uludağ'a (2010: 313-314) göre faiz olayı ile enflasyon başka başka olaylar olmakla beraber, ekseriya iç içe bulunmaktadır. Faizin enflasyonu karşılayan kısmı faiz değildir. Çeker'e (2013: 245) göre, paranın değer kaybını/enflasyon farkını tek maddeye kıyas ederek hesap etmek yanlıştır. Paranın ne kadar değer kaybettiğini mesela tek başına altına veya tek başına bir dövize kıyaslayarak hesap etmek faizin doğurduğu fesada sebebiyet verebilir. Ne kadar çok kalem mala kıyas edilirse o kadar adil hesap yapılmış olur. Aktepe (2012: 32) göre de, borç verilebilir her türlü mal ve varlık borç olabilir. Bu bakımdan para borcu yanında altın ya da döviz borcu vermek de meşrudur. Alacaklının TL olarak verdiği borcun enflasyon karşısında değer kaybetmesi sebebiyle uğrayacağı zararı, enflasyon farkını talep ederek gidermesi mümkündür. 
tartışmalar, doğurduğu sonuçların sorumluluğunu taşıyacaktır. Bundan dolayı, iktisadi sistemin içeriği hakkında duyulan İslami endişe, teorinin oluşturulması sırasında da hissedilmeli ve dikkatli olunmalıdır.

\subsubsection{Finansmana Erişimde Adaletin Sağlanmasında Katılım Bankacılığının Etkinliği Kamu Destekleriyle Artırılmalı}

Finansal kurumların kaynakları nüfusun geniş bir kesiminden gelen teminatlardan oluştuğu için rasyonel olan hareket, bu kaynaklara tıpkı kamusal bir rezervuardan gelen su kaynağı gibi milli bir kaynak muamelesi yapılmasıdır. Varlıklı ve güçlü olanların daha da zenginleşmesi için değil nüfusun tüm kesimlerinin refahı için kullanılmalıdır (Chapra: 2018: 343). Bunun için de finansal kaynaklar, en yaygın istihdam şartlarını hazırlayacak KOBI'ler ve toplumun ihtiyacı olan mal ve hizmetlerin gerekli miktardaki üretimini sağlayacak kişi ve kurumlar arasında adil bir şekilde dağıtılmalıdır. Bunun için de katılım bankacılığı, kamu tarafından verilecek gerekli teşviklerle desteklenmelidir. Aksi durumda finansmana erişimde adil olmayan durum devam edecektir.

Chapra (2018: 345) çalışmasında bu konuda şu tespitlerde bulunmuştur: Kredilerin adil bir şekilde dağılmadığ sağlanması hedefi, toprak reformları yapılsa dahi finansal sistemin servetin yoğunlaşmasını şiddetlendirme eğilimi düzeltilmeden ancak boş bir ümit olarak kalmaya mahkûmdur. KOBİ'lerin kırsal ve kentsel bölgelerde yayılması ile temel ekonomik problemler olan yoksulluğun ve işsizliğin çözülmesi bile, KOBI'lerin finansmanı için gerekli düzenlemeler yapılmadığı sürece benzer bir şekilde temelsiz bir umut olacaktır. Finansman eksiği, küçük çiftliklerin ve KOBI'lerin gelişiminin önündeki en büyük engeldir. Yoksullar sıkı çalışmak ya da gerekli becerilere sahip olmadıkları için yoksul değildirler. Hatta zenginlerden daha fazla çalışmaktadırlar ve kullanabileceklerinden daha fazla beceriye sahiptirler. Onların sorunu kendi işlerini kurmak için gerekli finansal kaynaklara erişim sağlayamadıkları ve ücretli istihdam seçeneklerinin ya onların becerilerinden en iyi şekilde faydalanmamaları ya da yatırım yapmak üzere birikim yapmak bir yana, kendi ihtiyaçlarını karşılayacak kadar bile ödeme yapmamalarıdır.

$\mathrm{Bu}$ olumsuzlukların azaltılabilmesi ve sonraki başlıktaki amaçlara da ulaşılabilmesinde kamu tarafından verilecek desteklerin (pozitif kayırmacılıkla) artırılması gerekmektedir. Türkiye'de uygulanmakta olan Kredi Garanti Fonunun, katılım bankacılığındaki uygulanma şekli hakkında Chapra (2018: 348) çalışmasında şu öneride bulunmaktadır: Risk, kısmen devlet tarafından kısmen ticari bankalar tarafından üstlenilen bir kredi garanti planıyla azaltılabilir. İslami bankalar söz konusu olduğunda ise garanti planı, ana akım bankalarda olduğu gibi kredilerin faizleriyle birlikte geri ödenmesini içeremez. Plan daha ziyade finansmanın moral riskini kapsamalı ve bankayı, yeterlilikleri garanti planı dâhilinde değerlendirilecek ve belgelendirilecek olan KOBİ'lerden teminat istemekten kurtarmalıdır. Bu şekilde çok sayıda KOBİ, ana akım bankalar tarafindan talep edilen teminatı bir araya getirmek zorunda kalmadan bankalardan, finansman sağlayabileceklerdir. Bir piyasa aksaklığı ve sonuç olarak çıkan bir zarar durumunda, banka işletmeye sağladığı finansmanın oranına bağlı olarak sonuçlardan kendi payını alacaktır. Plan aynı zamanda KOBI'lerin fonlara erişimini kolaylaştırabilmek için diğer ticari olmayan risklerin karşılanması gereken bir kısmını da kapsayacaktır.

\subsubsection{KOBİ'lerin Finansmana Erişimindeki Zorlukların Azaltılmasında Katılım Bankacılığının Rolü Artırılmalı}

KOBİ'lerin finansmana erişiminde karşılaştıkları en büyük engel, finansörlere, gerekli teminatları gösterememeleridir. Chapra'ya (2018: 347) göre KOBİ'leri finanse etmenin riskli olması, bankaların onlardan karşılamaları mümkün olmayan yüksek miktarlarda teminat istemesine neden olmaktadır. Bu, KOBİ'lerin, istihdam, çıktı ve gelir dağılımına yapabilecekleri büyük katkılara karşın büyümelerini ve yayılmalarını engellemektedir. Finansman, genel olarak 
kendilerinden daha az teminat istenen ve bu teminatı da sahip oldukları servet sayesinde hiçbir güçlük yaşamadan karşılama kapasitesine sahip olan zenginlere verilmektedir.

$\mathrm{Bu}$ yüzden sadece verilen kredinin teminatlarının sağlamlığına bakan geleneksel yaklaşımın terk edilmesi gerekmektedir. Faizsizlik esasına göre çalışan katılım bankacılığının yaklaşımı, daha ileri boyuta taşınarak, finansman verilen veya yatırım yapılan projeye ortaklık yapılıyormuş, kar/zarar paylaşıyormuş gibi bakmak olmalıdır. Gedikli ve Erdoğan'a (2016: 243) göre de katılım bankacılığı modelinin risk paylaşımı esasına dayanması, finansör ile proje arasında mutlak bir bağ kurarak, riskin paylaşılmasına ve doğal olarak da riskli varlıklardan belli başlı türev araçlarına yönelik yatırımlardan kaçınılması konusunda otomatik bir stabilizatör rolünü üstlenmesine neden olmuştur.

Katılım bankacılığının, sadece verdiği kredilerin teminatının sağlam olmasına bakmadan, öncelikle projelerin olabilirliğini araştırması, hem onun hem de şirketlerin risk yönetimini kolaylaştıracaktır. Dolayısıyla şirketlerin, gerek kurumsallaşma eksikliği gerekse de işletme körlüğ̈̈n̈̈n ortaya çıkaracağı sorunlar daha kolay yönetilebilecektir. $\mathrm{Bu}$ beklentilerin gerçekleşebilmesi katılım bankacılı̆̆ında çalışanların sorumluluklarını artıracağından, gerekli donanımlara sahip olmaları sağlanmalıdır. Böylece emek/sermaye ortaklığındaki bankacılar, hem sermayedarı hem de şirketin haklarını temsil etme, koruyabilme yetilerine sahip olabileceklerdir.

\subsubsection{Bireysel ve Kurumsal Müșterilere Yönelik Sermaye Piyasalarında Katılım Bankacılığının Payı Artırılmalı}

Katılım bankacılığının çalışma şekliyle uyumlu olan ${ }^{7}$ veya olacak şekilde, sermaye piyasası araçlarıyla; hem bireysel müşterilerine yönelik hem de kurumsal müşterilerine yönelik geliştirebileceği finansal araçlarla sermaye piyasalarında faaliyette bulunabilme potansiyeline sahiptir. Buradaki yaklaşım şekli, emek/sermaye ortaklığındaki mantığı esas alarak, hem faizsiz ürünleri lanse etmek hem de finansal okuryazarlık seviyesinin yükseltilebilmesine yönelik olmalıdır ki, önceden var olan güvensizlik ortadan kaldırılabilsin. Zira doğrudan finansman imkânı sağlayan sermaye piyasalarının Türkiye'de gelişememesinin en önemli nedeni budur. $\mathrm{Bu}$

durumun tersine çevrilmesi için de önceden ifade edildiği gibi, başta finansal sistem düzenleyicileri olmak üzere tüm tarafların, ilgili sektör temsilcilerinin (Türkiye Katılım Bankaları Birliği, Türkiye Bankalar Birliği vb.) yakın çalışması gerekmektedir. Finansal tüketici ve ticari müşterilere yönelik ortak planlama ve icraatla yürütülecek eğitimler sonucunda ve geliştirilecek sermaye piyasası aracılı̆̆ıyla hem tasarruf sahibi hem de fon talep edenler sadece para piyasalarına, kısa dönemli enstrümanlara bağımlı kalmayacaklardır.

Türkiye'de son dönemlerde, katılım bankacılığının ve sermaye piyasalarının payının artırılabilmesi için ilgili tarafların çalışmaları dikkat çekicidir. Ürünler geliştirilebilmesi için mevzuatta gerekli olan güncellemeler sürekli yapılmaktadır. Türker de (2010: 48) çalışmasında şu önerilerde bulunmaktadır: İslami kurallara uygun olarak fon oluşturma ve yönetme açısından mevzuat engeli bulunmayan ülkemizde bu konudaki imkânlara yönelik bilinçlendirme ve farkındalığa yönelik çalışmaların hem yatırıme hem de aracılar bağlamında yapılması gerekmektedir. $\mathrm{Bu}$ konunun kurumsal yatırımların teşviki açısından da önem taşıdığı düşünülmektedir. $\mathrm{Bu}$ anlamda, hem yatırımcı hem de aracı tarafında bilincin artırılması ve fonlar açısından imkân ve firsatların değerlendirilebilmesi amacıyla eğitim ve bilgilendirme programları düzenlenmesinin uygun olacağı düşünülmektedir.

\footnotetext{
${ }^{7}$ Temel felsefesi kar/zarar ortaklığı şeklinde çalışmak olan katılım bankacılığ 1 Karahan ve Ersoy’a göre de (2016: 111) finansal işlemlerin, İslami esaslara uygun olarak yapılması gerekliliğinden, konvansiyonel finansal sisteme bir alternatif olarak ortaya çıkmıştır. Bu sistemin de temelinde insanın ve dolayısıyla toplumun zararına olduğu düşünülen faizin yasaklanması, yapılan işlemlerin faiz yerine ortaklık prensibinden yola çıkılarak kazancın da zararın da adilane bir şekilde paylaşılması esası vardır.
} 
Ezcümle, bu süreçte çok dikkatli ve sabırlı olunması gerekmektedir. Çünkü finansal sistemdeki ana akım küresel ve yerel finansal kurumlar da boş durmamaktadırlar. Asutay'ın (2012: 101) çalışmasında belirttiği gibi: İslami banka ve finansal kurumlar, mevcut geleneksel ekonomik ve parasal sistem içinde çalışır ve bu sistemin neden olduğu hareketlerden etkilenmesi kaçınılmazdır.

\section{Sonuç}

Kapitalist sistemde, bireyin yalnızca kendi çıkarını maksimize etmeye yönelik davranışlarıyla yaşanan çıkar çatışmalarına çözüm olarak önerilen sosyalist sistemde de, sınıf çatışmaları ve her iki yaklaşımın uygulama sonuçlarında iktisadi faaliyetlerin sürdürülebilirliğinde sorunlar ortaya çıkmıştır. Başka bir ifadeyle ana akım iktisadın temel görüşleri olan hissedarlar kapitalizmi ile devlet kapitalizmi arasındaki uygulamalar soncunda ekosistemi yok edici uygulamalar egemen olmuştur. Her iki uç yaklaşımın iflas ettiği günümüzde, bunun temel sebebi olan işletmelerden ve/veya sermayedarlardan daha fazlasını yapması bekleniyor ki, amaç sürdürülebilir kalkınmanın sağlanabilmesidir. Bunun mümkün olabilmesi için tüm tarafları kapsayan paydaşlar kapitalizmi kavramı kullanılmaya başlamıştır.

Bu kavramla ulaşılmak istenen amaç ekonomik gelişmişlik seviyesinin artırılmasıyla birlikte, sosyal, kültürel, çevresel vb. gibi faktörlerde, hem bireylerin hem de toplumların yaşam kalitelerinde olumlu yöndeki değişimleri gerçekleştirmektir. Bu şekildeki yapılanmanın öznesi olan işletme faaliyetlerinin yürütülmesinde amaç sadece kârlılı̆̆ın artırılması olmamalıdır. Paydaşlar, karın artırılması için en iyi araçlar olarak görülmemelidir. Şirketler, gelirlerini, katkıları ölçüsünde çalışanlarıyla, tedarik zincirinde yer alan diğer firmalarla, müşterileriyle; kısacası, üretimde ve sonrasındaki süreçte direkt veya dolaylı yer alan tüm aktörlerle paylaşmalıdırlar.

Bu paylaşım gönüllü olamayacağına göre, hem yerel hem de küresel ölçekteki düzenleyici ve denetleyici kurumlara büyük görevler düşmektedir. Bu kurumlar, özel veya kamu sektöründe, hizmet arzından mamul geliştirmeye; ticari faaliyetlerin veya kamu hizmetlerinin düzenlenmesinden denetlenmesine kadar; günlük yaşama ait her alanda uygulanabilecek bir fikir, davranış ve iş yapış şekli için sistemi düzenleyebilecek kapasitelere kavuşturulmalıdır.

İnsanoğlu bu sistemleri, deneme/yanılma yoluyla bulmaya ve kurallaştırmaya çalışırken (yani paydaşlar kapitalizminin gelir ve servet dağılımında adaleti sağlamak amacına) İslam, bunun nasıl gerçekleştirileceği konusundaki özgün (faizin haram olması, zekât, fitre vb.) araçlarıyla çözüm bulmuştu. Dolayısıyla paydaşlar kapitalizminin amaçlarına ulaşılmasını sağlayacak iktisadi yap1 ve onu etkileyen finansal sistem, denenmiş ve paydaşlar yerine sadece sermayedarlara ve hissedarlara hizmet etmiş geleneksel bankacılık yerine, faizsizlik prensibine göre çalışacak katılım bankacılığı olmalıdır.

Türkiye'de katılım bankacılığının gelişememesinin önemli bir sebebi "enflasyon, faiz, devalüasyon" sarmalının yaşanmasıdır. Türkiye'de enflasyonun hem düşmesi hem de enflasyon belirsizliğinin azalması, bu sistemin gelişmesi önündeki engellerin büyük ölçüde ortadan kalkması demektir. Tersi durumunda çeşitli nedenlerle yerel paranın, iç ve dış değerinde meydana gelecek düşüşler, onun değer saklama özelliğini olumsuz yönde etkilemektedir. Dolayısıyla Müslüman bireyler, gerek faize bulaşmama gerekse de finansal sisteme olan güvensizlikleri nedeniyle yastıkaltı tasarruflara veya para ikamesine yönelmektedirler. $\mathrm{Bu}$ durumun kısa dönemde hafifletilebilmesi için bu kesimlerin tasarruflarını, enflasyon oranlarına; döviz veya altın gibi ürünlere endeksli yatırım araçlarına; gerçekçi piyasa fiyatlamalarına bağlı yeni sistemlere yönlendirecek araçların katılım bankalarınca geliştirilebilmesi gerekmektedir. Böylece hem fon talep eden yatırımciya hem de tasarruf sahibine sunulabilecek faizsiz yeni ürünler sayesinde, katılım bankalarının ekonomi içerisindeki ağırlı̆̆ı artabilecektir.

Geleneksel finans sistemlerinin önemli bir diğer sorunu da, onların kaynaklarından yararlanmada adil olmayan bir dağlım vardır. Bu kaynakların varlıklı ve güçlü olanlar yerine, en 
yaygın istihdam şartlarını hazırlayacak KOBI'ler ve toplumun ihtiyacı olan mal ve hizmetlerin gerekli miktardaki üretimini sağlayacak kişi ve kurumlar arasında adil bir şekilde dağıtılması sağlanmalıdır. Bunun için de katılım bankacılığı, kamu tarafından verilecek gerekli teşviklerle desteklenmelidir. Aksi durumda finansmana erişimde adil olmayan durum devam edecektir.

Katılım bankacılığı çalışma prensipleriyle uyumlu olan sermaye piyasası araçlarıyla, bireysel ve kurumsal müşterilerine yönelik geliştirebileceği finansal araçlarla sermaye piyasalarında faaliyette bulunabilme potansiyeline sahiptir. Buradaki yaklaşım şekli, emek/sermaye ortaklığındaki mantığ 1 esas alarak, hem faizsiz ürünleri lanse etmek hem de finansal okuryazarlık seviyesinin yükseltilebilmesine yönelik olmalıdır ki, önceden var olan güvensizlik de ortadan kaldırılabilsin. Dolayısıyla katılım bankacılı̆̆ı ve sermaye piyasalarının birliktelik gücü ve sinerjisiyle büyümeleri daha kolay gerçekleşebilsin. Finansal sistemdeki bu dönüşümün sağlanmas1 yanında hem yerel hem de küresel ölçekteki bağımsız düzenleyici ve denetleyici yapıların kurulması ve işletilmesi büyük önem taşımaktadır. Bu yapıların kurulması sonrasında işletilebilmesi de, her seviyedeki yapılarda kurumsallaşmadaki başarıya bağlıdır.

Kısacası, paydaşlar kapitalizminde tüm tarafları etkileme gücüne sahip finansal sistemde ve finansmana erişimde adil olmayan geleneksel araçlardaki dönüşümün; katılım bankacılığı ve sermaye piyasalarının birlikteliğinin sağlanamaması; bağımsız düzenleyici ve denetleyici yapıların etkin çalışmaması paydaşlar kapitalizminin amacına ulaşmasını zorlaştıracaktır.

\section{Kaynakça}

Abdullahoğlu, S. (2014). İslam ekonomisi çalışmak. Sercan Karadoğan (Ed.), İslam Ekonomisi Tanım ve Metodoloji Üzerine. İslam Ekonomisi Enstitüsü Yayınları, 15-22.

Acemoğlu, D. \& Robinson, J.A. (2016). Ulusların düşüşü güç, zenginlik ve yoksulluğun kökenleri. Faruk Rasim Velioğlu (Çev.), 11. Bask1. Doğan Kitap.

Adıgüzel, Z., Tepe, S. \& Erdil, O. (2020). Paydaş ilişkileri yönetimi ve paydaş davranışı etkileri firma performansını etkiler mi? Telekom şirketlerinde araştırma. Turkish Studies Economy, 15(3), 1067-1086. https://dx.doi.org/10.47644/TurkishStudies.43849

Aktepe, İ.E. (2012). Sorularla katılım bankacılı̆̆g. Türkiye Katılım Bankaları Birliği Yayın No: 4.

Altıntaş, A. (2012). Kredi kayıplarının makroekonomik değişkenlere dayalı olarak tahmini ve stres testleri-Türk bankacılık sektörü için ekonometrik bir yaklaşım. Türkiye Bankalar Birliği, G. M. Matbaacılık ve Ticaret A.Ş.

Asutay, M. (2012). Conceptualising and locating the social failure of Islamic finance: aspirations of Islamic moral economy vs. the realities of Islamic finance, Asian and African area studies, 11(2), 93-113. u.ac.jp/dl/publications/no_1102/AA112_02_Asutay.pdf https://www.asafas.kyoto-

Ayub, M. (2017). İslami finansı anlamak. Suna Akten Çürük ve Raif Parlakkaya (Çev. Ed.). İktisat Yayınları.

Bankalarımız (2020). Bankalarımız 2019. Türkiye Bankalar Birliği Yayın No: 336, Mayıs 2020. https://www.tbb.org.tr/Content/Upload/Dokuman/7678/Bankalarimiz_2019.pdf

Bilgili, F. \& Demirkapı, E. (2016). Borçlar hukuku. Dora Basım Yayın.

Chapra, M. U. (2018). İktisadi tehditler ve islam, Gülnihal Kafa (Çev.). İktisat Yayınları-14.

Çeker, O. (2013). Fetvalarım - 1. Damla.

Dede, K. (2017). Katılım bankalarında hazine ürünleri ve sermaye piyasası uygulamaları, TKBB Yayınları, Yayın No: 5. 
Demir, Ö. (2013). Din ekonomisi inanç, zenginlik ve mutluluk. Sentez Yayınc1lık.

Eğri, T. (2017). İslam iktisadını yeniden düşünmek, Taha Eğri, Necmettin Kızılkaya ve Oğuz Karasu (Ed.). İktisat Yayınları 2. Bask1.

Er, S. (2011). Finansal krizleri önleme aracı olarak finansal sektörün regülasyonu, mortgage krizi ve Türkiye. Maliye Dergisi, Say1 160, Ocak-Haziran 2011, 307-327.

Eroğlu, İ. \& Kangal N. (2016). İslami düşünce ekseninde enflasyon, Seyfettin Erdoğan, Ayfer Gedikli ve Durmuş Çağrı Yıldırım, (Ed.), İslam Ekonomisi ve Finansı, Umuttepe Yayın No: $180,315-330$.

Friedman, M. (1970). The social responsibility of business is to increase its profits, The New York Times Magazine, $\quad$ September 1970. https://graphics8.nytimes.com/packages/pdf/business/miltonfriedman1970.pdf

Gedikli, A. \& Erdoğan, S. (2016). Katılım bankacılığı: Türkiye ve Dünya uygulaması, Seyfettin Erdoğan, Ayfer Gedikli ve Durmuş Çağrı Yıldırım, (Ed.), Islam Ekonomisi ve Finansı. Umuttepe Yayın No: 180, 195-248.

Günal, M. (2010). Para banka ve finansal sistem. Nobel Yayın No: 1603, 3 Basım.

Karacan, S. \& Savcı, M. (2011). Kriz dönemlerinde işletmelerin mali başarısızlık nedenleri. Kocaeli Üniversitesi Sosyal Bilimler Enstitüsü Dergisi, (21) 2011 / 1, 39-54.

Karahan, H. \& Ersoy, H. (2016). Faizsiz finansin temel prensipleri ile türkiye'de reel kesimde kullanılması, Maliye ve Finans Yazıları, Say1: 105, 93-114.

Karaman, H. (2012). İş ve ticaret ilmihali. İz Yayıncılık.

KGK. (2020). Faizsiz finans denetim standartlarına ilişkin kurul kararları. https://www.kgk.gov.tr/ContentAssignmentDetail/4627/Faizsiz-Finans-Denetim\%20Standartlar\%C4\%B1na-I\%CC\%87lis\%CC\%A7kin-Kurul-Kararlar\%C4\%B1-14Aral\%C4\%B1k-2019-tarihli-ve-30978-Say\%C4\%B11\%C4\%B1-Resmi\%CC\%82Gazetede-Yay\%C4\%B1mlanm\%C4\%B1s\%CC\%A7t\%C4\%B1r-).

Millstein, I. M. (2020). Kurumsal yönetim nedir? http://www.tkyd.org/files/downloads/hakkimizda/TKYD\%20Kurumsal\%20Yonetim\%20N edir\%202017.pdf

Mishkin, F.S. (2007). The economics of money, banking, and financial markets, Eighth Edition, Pearson addison Wesley.

Naqvi, S.N.H. (2019). Ahlaklı olmak ve insanın esenliği üzerine görüşler islam iktisadına bir katkı. Miraç Çeven (Çev.). İktisat Yayınları-28.

OECD (2005). Improving financial literacy: analysis of 1 ssues and policies. https://books.google.com.tr/books?id=q5QcxootQFYC\&printsec=frontcover\&hl=tr\&sourc $\mathrm{e}=\mathrm{gbs} \_g e$ _summary_r$\& \mathrm{cad}=0 \# \mathrm{v}=$ onepage $\& \mathrm{q} \& \mathrm{f}=$ true

On Birinci Kalkınma Planı (2019-2023). 100. Yı1 Türkiye Planı, Türkiye Cumhuriyeti Cumhurbaşkanlığı Strateji ve Bütçe Başkanlığı. http://www.sbb.gov.tr/wpcontent/uploads/2019/11/ON_BIRINCI_KALKINMA-PLANI_2019-2023.pdf

Oktar, S. \& Dalyanc1, L. (2010). Finansal kriz teorileri ve Türkiye ekonomisinde 1990 sonras1 finansal krizler. Marmara Üniversitesi I.I.I.B.F. Dergisi, Y11 2010, Cilt: XXIX, Say1: II, 122.

Orman, S. (2014). İslami iktisat, değerler ve modernleşme üzerine. İnsan Yayınları.

Özsoy, İ. (2012). Fıkıh doktrininde para ve faiz, Halit Çalış (Ed.), Fıkhi Açıdan Finans ve Altın Isslemleri. Ensar Yayınları, 75-132. 
Öztürk, M. (2017). Adil ekonomik düzen'de artı(k) değerin paylaşımı / sharing the surplus in the just economic order", TURKISH STUDIES -International Periodical for the Languages, Literature and History of Turkish or Turkic-, ISSN: 1308-2140, (Millî Görüş Özel Saylsı) Volume 12/8, www.turkishstudies.net, http://dx.doi.org/10.7827/TurkishStudies.11715, 149-170

Öztürk, Y.K. \& Akdağ, İ. (2017). Kapitalist sistemin kriz ve yükselişleri: uzun dalgalar teorisi. Turkish Studies International Periodical for the Languages, Literature and History of Turkish or Turkic, 12(24), 147-158. http://dx.doi.org/10.7827/TurkishStudies.12313

Rodrick, D. (2014). Kaliteli büyümeye yönelik kurumlar: nelerdir ve nas1l kazanılır? Ahmet Faruk Aysan ve Devrim Dumludağ (Ed.), Kalkınmada Yeni Yaklaşımlar, İmge Kitabevi, 37-66.

Saraç, M. (2017). Finans teorisini yeniden düşünmek, İktisat Yayınları.

Schwab, K. (2020). Davos manifesto 1973: a code of ethics for business leaders. https://www.weforum.org/agenda/2019/12/davos-manifesto-1973-a-code-of-ethics-forbusiness-leaders

Şiriner Önver, M \& Şirin Pınarcıŏglu, N. (2018). Kapitalizmde çöp sorunu. Turkish Studies Current Debates in Social Sciences (CUDES-2018), 13(23), 239-254. http://dx.doi.org/10.7827/TurkishStudies. 14233

Tabakoğlu, A. (2005). İslam ekonomisinde emek ve sermaye kavramları, Toplu Makaleler-2: Íslam İktisad, Kitabevi Yayınları, 125-137.

TKYD. (2020). Kurumsal yönetim nedir? http://www.tkyd.org/files/downloads/hakkimizda/TKYD\%20Kurumsal\%20Yonetim\%20N edir\%202017.pdf

Tokalak, İ. (2016). Kapitalizmin soygun düzeni dünyayı soyanlar ve metodları. Ataç Yayınları.

Turhan, İ. (2013). Faizsiz finans ve katılım bankacıllı̆ı: dünden yarına firsatlar, Güler Aras (Ed.), Türkiye Finans Piyasasının Derinleşmesinde Faizsiz Finansman ve Yatırım Araçlarının Önemi Konulu 5 Aralık 2011 Tarihinde Gerçekleşen Toplantı, Albaraka Türk Yayınları: 41, 14-28.

Türker, H. (2010). İslami finans sisteminde finansal aracllk: Dünyadaki gelişmeler ve sermaye piyasasının geliştirilmesi açısından Türkiye için öneriler [Yeterlik Etüdü]. Sermaye Piyasası Kurulu Aracılık Faaliyetleri Dairesi.

Uludağ, İ. \& Arıcan, E. (1999). Finansal hizmetler ekonomisi (piyasalar-kurumlar-araçlar). Beta Yayın No: 895.

Uludağ, S. (2010). İslam'da faiz meselesine yeni bir bakış. Dergâh.

WEFORUM, (2020). Davos manifesto 2020: the universal purpose of a company in the fourth industrial revolution. https://www.weforum.org/agenda/2019/12/davos-manifesto-2020the-universal-purpose- of-a-company-in-the-fourth-industrial-revolution/

Yahşi, F. (2013). Türkiye finans piyasasının derinleşmesinde faizsiz finansman ve yatırım araçlarının önemi konulu 5 Aralı 2011 Tarihinde Gerçekleşen Toplantıda Panelist, (3643), Güler Aras (Ed.). Albaraka Türk Yayınları: 41.

Yazıcı, R. (2017). Finansal sistemde faiz sorunsalı ve katılım bankacıllğ̆. Kriter Yayınevi.

Yazıcı, A. \& Yazıcı, R. (2017). İşletmelerde kurumsal değişim ve ekonomik kalkınmada kalite yönetim sistemlerinin önemi: Türkiye örneği, Journal of Current Researches on Business and Economics, 7 (2), 17-26. 